\title{
Estrogenic Compounds in Estuarine and Coastal Water Environments of the Iberian Western Atlantic Coast and Selected Locations Worldwide - Relevancy, Trends and Challenges in View of the EU Water Framework Directive
}

\author{
Maria João Rocha and Eduardo Rocha \\ Additional information is available at the end of the chapter \\ http://dx.doi.org/10.5772/59885
}

\section{Introduction}

Water is vital to life and thus its availability and quality has increasingly been the object of intense concern and disputes by multiple agents that include from people directly relying on ecological services, or simply living in impacted zones, to influential non-governmental environmental organizations and regulatory governmental authorities. The scientific community has increasingly intervened, particularly through the production of sound diagnostic and mechanistic data and also prognostic models, which fundamentally rely on both chemical and biological environmental monitoring. Despite the global increasing of pollution and its impacts, it appears that there is an uncontrollable expansion of anthropogenic activities, mainly in countries where there are no strict environmental policies. Therefore, pollution continues to negatively affect the quality of water and, in consequence, the vast ecosystems associated with it. Presently, it is estimated that hundreds of new chemicals with harmful potential are recorded daily in the CAS® (Chemical Abstracts Service, http://www.cas.org/ cashome). Thus, the subject "Water Quality" has been the target of many reflections, particularly in Europe, where in general, all state members of the European Union (EU) have shown their concern about the near future possibility of water shortages, for all, both in quantity and quality [1]. Related to this aspect, it is also recognized as of major importance the need to protect biodiversity and natural ecosystems; an example of such recognition is depicted in the 2012 European Parliament resolution on the "EU Biodiversity Strategy 2020" [2]. 
In line with the referred intentions, at the beginning of the millennium the EU adopted legislation - the EU "Water Framework Directive" (WFD) [3] - that was considered very innovative at the time. The WFD called for a comprehensive and integrated approach of water protection and management, having as its ultimate goal that all European waters (continental surface waters, transitional waters, coastal waters and groundwaters) reached good chemical and ecological status within a 15 years period, since the date of publication of that directive. To achieve these requirements, temporal incremental goals were established amongst all EU states to ensure the success of this program. Thus, it was decided inter alia to: (i) apply all necessary measures to avoid the damage of superficial water bodies; (ii) impose fines on violators responsible for deteriorating the status of surface water bodies; (iii) achieve good ecological and chemical status for all artificial or heavily modified water bodies; (iv) progressively reduce the pollution of priority compounds, some of these focused in this Chapter, by limiting their emissions, their discharge and/or runoff into the environment.

However, as the water situation in each EU state was different and unique, since 2000 and up to the present, it has been necessary to make adjustments to overcome this aspect. Indeed, just one year after the WFD 2000/60/EC publication, this directive was updated [4]. In the renovated document (2455/2001/EC), among other measures, it was published a list containing thirtythree harmful compounds which presence in surface waters should be limited or at least/ reduced under limit values [4]. Among these compounds stands out the persistent organic pollutants (POPs), such as, pesticides, polycyclic aromatic hydrocarbons and alkylphenols. Later, the number of harmful compounds were expanded up to forty five and additional environmental quality standards were included in (2008/105/EC) [5]. Nonetheless, because further toxicity details each pollutant are becoming known, the number of compounds in the WFD list tends to increase. In this vein, the current directive 2013/39/EU integrates new substances in its watch lists [6]. Among those are EDCs such as the extremely potent 17ßoestradiol $\left(\mathrm{E}_{2}\right)$ and $17 \alpha$-ethinylestradiol $\left(\mathrm{EE}_{2}\right)$, as discussed in this Chapter.

\section{Estrogenic endocrine disrupting compounds in surface waters}

Accordingly to the National Institute of Environmental Health Sciences (USA), endocrine disrupting compounds are natural or man-made compounds that may mimic or interfere with the function of hormones in the body, producing a variety of adverse effects over the reproductive, the neurological and the immune systems of humans and both domestic and wild animals [7]. In the case of EDCs with oestrogenic activity, these substances can act: (i) on the hypothalamus, inhibiting the release of gonadotropin releasing hormones [8]; (ii) on the pituitary, inhibiting the release of gonadotropins [8]; (iii) on the gonads, interfering with the production of steroid hormones, namely $\mathrm{E}_{2}$ [9]; (iv) on the circulation of endogenous hormones, as these compounds have the ability to bind to the same plasmatic carriers [8]; (v) on the same cellular receptors used by the endogenous hormones causing important structural changes [10]. In males of various fish species, situations of ovotestis, i.e., presence of oocytes in testes, were reported in polluted systems that include some in Portugal [11]. 
Here, it is exposed the environmental concentrations of sixteen oestrogenic EDCs, which were chosen taking in account the following features: (i) in vivo and in vitro potency, such as the natural oestrogens and $\mathrm{EE}_{2}$ [12]; (ii) abundance in terms of incidence and concentration), such as bisphenol $\mathrm{A}$ and the alkylphenols (and their ethoxylates) [13, 14], and (iii) the ubiquitous, but paradoxically less studied, phytoestrogens [14, 15].

\subsection{Oestrogens}

\subsubsection{Main characteristics and environmental origins}

Both natural and synthetic oestrogens, including oestrone $\left(E_{1}\right), E_{2}$ and $E_{2}$ (Figure 1) may induce, even in low (ng/L) concentrations, from mild to extremely harmful effects over the endocrine system [16]. In particular, these compounds have been associated with the occurrence of endocrine disorders such as those over the reproductive system of a wide range of species, including molluscs, crustaceans, fish, birds and mammals [17-22]. Another disruption effect observed in animals, collected from waters containing high levels of oestrogenic contamination, is the decrease of their immune system responses disorders [23]; this phenomenon also seems to occur when humans are exposed to the same type of EDCs [24, 25]. These observations, together with the abovementioned facts, justified the recent incorporation of these compounds in the WFD watching lists [6]. In this sense, and in order to be aware about the concentrations of $\mathrm{E}_{1}, \mathrm{E}_{2}$ and $\mathrm{EE}_{2}$ in surface waters, studies were initiated to monitor their presence and appraise their temporal evolution. It is known that the primary sources of these three EDCs are their excretion by urine and faeces [26]. So, these compounds reach the rivers, estuaries and coastlines either through the discharge of effluents coming from sewage treatment plants (STPs) - or directly from sewages (hence untreated) that deliver their content into waterways.

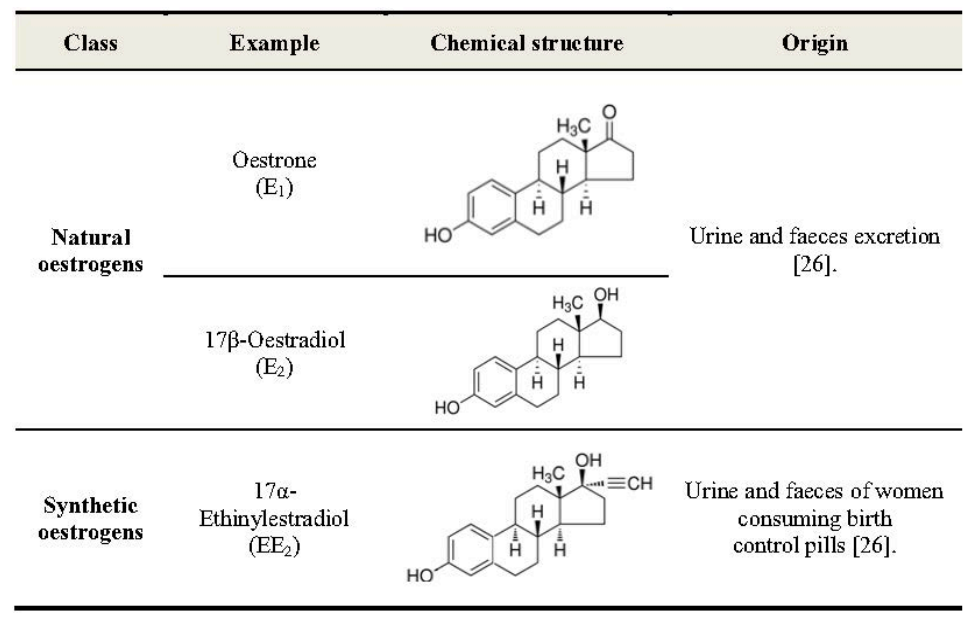

Figure 1. Natural and synthetic oestrogens included $\left(E_{2}\right.$ and $\left.E_{2}\right)$ or to be included $\left(E_{1}\right)$ in the watch list of compounds under surveillance by the WFD [6]. 
Although the concentrations of the referred EDCs are typically in the order of few ng/L (Table 1), it has been experimentally proven that such amounts are potentially harmful [12]. For example, just $4 \mathrm{ng} / \mathrm{L}$ of $\mathrm{E}_{2}$ resulted in the formation of ovotestis in male Japanese medaka (Oryzias latipes) [27]. Also the male mummichog (Fundulus heteroclitus) exposed to $100 \mathrm{ng} / \mathrm{L}$ of $\mathrm{EE}_{2}$ showed a large increase in the gonadosomatic index, decrease in testosterone production and liver synthesis of vitellogenin [28].

\subsubsection{Oestrogens in surface waters}

The highest concentrations of $E_{1}$ in surface waters were reported in Japan (Tama River) [29], Taiwan (Shui-Dan River) [30] and, China (Pearl Rivers) [31, 32] where its levels ranged from78.7 ng/L to $85.6 \mathrm{ng} / \mathrm{L}$. The highest amounts of $\mathrm{E}_{2}$ were measured in Italy (Venice Lagoon), Japan (Tama River) and Taiwan (Shui-Dan River) where its levels ranged from12 ng/L to175 $\mathrm{ng} / \mathrm{L}$. Finally the highest levels of $\mathrm{EE}_{2}$ were found in Spain (Ebre River) [33], China (Pearl Rivers) [31, 32] and Italy (Venice Lagoon) [34] where its levels ranged from 34 to $130 \mathrm{ng} / \mathrm{L}$. From the in vivo and in vitro experiments referred in section 3.1.1., among many other, it is concluded that those levels are environmental conditions for the occurrence of endocrine disrupting events. In north/central Europe, the surface water concentrations of these compounds are typically lower than those described in Asia and Brazil (Table 1). Even so, significant biological impacts associated with pollution were detected in Europe. For example, roach (Rutilus rutilus) and gudgeon (Gobio gobio) males caught in rivers and estuaries of the United Kingdom showed high occurrence of ovotestis [35-38]. In Portugal, in the early 2000s, ovotestis was observed in flounder (Platichthys flesus) and mullets (Mugil cephalus) caught from Douro estuary [11]. However, as it can be seen from Table 1, at that time no information existed about the degree of oestrogenic contamination in Iberian western Atlantic coast surface waters - this led to our integrated studies shown in this Chapter, which first data were published in 2009 (Table 2).

\begin{tabular}{|c|c|c|c|}
\hline EDC & Sampling area & Concentration (ng/L) & References \\
\hline & Estuarine and coastal waters, The Netherlands & $0.1-3.4$ & [26] \\
\hline & Scheldt Estuary, Belgium - The Netherlands & ND -10.0 & [39] \\
\hline & The Netherlands (surface water) & $<0.30-7.2$ & [40] \\
\hline & Rivers in Germany & $0.10-4.1$ & [41] \\
\hline & Coastal area of Baltic Sea, Germany & $0.08-0.54$ & [42] \\
\hline & Seine River, France & $1.0-3.2$ & [43] \\
\hline \multirow[t]{7}{*}{$E_{1}$} & Tiber River, Italy & $5.0-12$ & [44] \\
\hline & Venice Lagoon, Italy & $<1.20-10$ & {$[34]$} \\
\hline & Ebro River, Spain & ND -4.9 & [56] \\
\hline & Llobregat River, Spain & $<$ LOD -22 & [45] \\
\hline & Llobregat River, Spain & $0.82-5.81$ & [46] \\
\hline & Thermaikos Gulf, Nothern Aegean Sea, Greece & $<\mathrm{LOD}$ & [47] \\
\hline & Buyukcekme watershed, Istambul, Turkey & $1.40-5.74$ & [48] \\
\hline
\end{tabular}




\begin{tabular}{|c|c|c|c|}
\hline \multirow[t]{11}{*}{ EDC } & \multirow{2}{*}{$\begin{array}{l}\text { Sampling area } \\
\text { Acushnet Estuary, USA }\end{array}$} & Concentration (ng/L) & \multirow{2}{*}{$\begin{array}{l}\text { References } \\
{[49]}\end{array}$} \\
\hline & & $0.73-1.20$ & \\
\hline & South Florida, USA & $0.88-5.20$ & [50] \\
\hline & Brazilian surface water & ND -39 & [51] \\
\hline & Tama River, Japan & $6.4-85.6$ & [29] \\
\hline & Dan-Shui River, Taiwan & $22.4-66.2$ & {$[30]$} \\
\hline & Yellow River, China & ND - 15.6 & [52] \\
\hline & Pearl rivers, South China & ND -78.7 & {$[31,32]$} \\
\hline & Yangtze River estuary, China & ND -1.43 & [53] \\
\hline & Songhua River, Northern China & ND - 3.05 & [54] \\
\hline & Tamagawa River, Japan & $3.4-6.6$ & [55] \\
\hline \multirow{21}{*}{$E_{2}$} & Estuarine and coastal waters, The Netherlands & $0.3-5.5$ & [26] \\
\hline & Scheldt Estuary, Belgium - The Netherlands & ND & [39] \\
\hline & The Netherlands (surface water) & $<0.8-1.0$ & [40] \\
\hline & Rivers in Germany & $0.15-2.0$ & [41] \\
\hline & Coastal area of Baltic Sea, Germany & ND & [42] \\
\hline & Seine River, France & $1.0-3.2$ & [43] \\
\hline & Tiber River, Italy & $2.0-6.0$ & [44] \\
\hline & Ebro River, Spain & ND -1.9 & [56] \\
\hline & Llobregat River, Spain & ND & [46] \\
\hline & Thermaikos Gulf, Nothern Aegean Sea, Greece & ND & [47] \\
\hline & Buyukcekme watershed, Istambul, Turkey & $1.10-5.39$ & [48] \\
\hline & Acushnet Estuary, USA & $0.56-0.83$ & [49] \\
\hline & South Florida, USA & ND -1.80 & {$[50]$} \\
\hline & Brazilian surface water & ND -7.3 & [51] \\
\hline & Tama River, Japan & $0.5-12$ & [29] \\
\hline & Dan-Shui River, Taiwan & $1.4-33.9$ & [30] \\
\hline & Yellow River, China & ND -2.3 & [52] \\
\hline & Pearl rivers, South China & ND - 7.72 & [32] \\
\hline & Yangtze River estuary, China & ND -1.4 & [53] \\
\hline & Songhua River, Northern China & ND - 1.16 & [54] \\
\hline & Tamagawa River, Japan & $0.6-1.0$ & [55] \\
\hline \multirow{6}{*}{$\mathrm{EE}_{2}$} & Estuarine and coastal waters, The Netherlands & $0.1-4.3$ & [26] \\
\hline & Scheldt Estuary, Belgium - The Netherlands & ND & [39] \\
\hline & The Netherlands (surface water) & $<0.3-0.4$ & [40] \\
\hline & Rivers in Germany & $0.1-5.1$ & [41] \\
\hline & Coastal area of Baltic Sea, Germany & ND - 17.9 & [42] \\
\hline & Seine River, France & $1.0-4.0$ & [43] \\
\hline
\end{tabular}




\begin{tabular}{|c|c|c|c|}
\hline EDC & Sampling area & Concentration (ng/L) & References \\
\hline & Ebro River, Spain & $30-130$ & [33] \\
\hline & Ebro River, Spain & ND & [56] \\
\hline & Llobregat River, Spain & ND & [46] \\
\hline & Tiber River, Italy & ND -1.0 & [44] \\
\hline & Venice Lagoon, Italy & $<1.0 \quad 34$ & [34] \\
\hline & Thermaikos Gulf, Nothern Aegean Sea, Greece & ND & [47] \\
\hline & Buyukcekme watershed, Istambul, Turkey & $11.7-14.0$ & [48] \\
\hline & Acushnet Estuary, USA & $3.01-4.67$ & [49] \\
\hline & South Florida, USA & NA & [50] \\
\hline & Brazilian surface water & ND -25 & {$[51]$} \\
\hline & Tama River, Japan & $<0.20$ & [29] \\
\hline & Dan-Shui River, Taiwan & $7.53-27.4$ & [30] \\
\hline & Yellow River, China & NA & [52] \\
\hline & Pearl rivers, South China & ND - 53.4 & {$[31,32]$} \\
\hline & Songhua River, Northern China & ND & [54] \\
\hline & Yangtze River estuary, China & ND - 0.11 & [53] \\
\hline
\end{tabular}

NA: Not Available. ND: Not Detected. LOD: Limit of Detection.

Table 1. Concentrations of oestrogens in surface waters (minimum-maximum) measured in surface waters worldwide.

\subsubsection{Oestrogens in surface waters from the west Iberian coast (Portugal)}

Being Portugal one of the EU members that signed the commitment with the European Commission (EC) to accomplish the directives referred in the WFD document, systematic efforts have been made by our research group to develop and validate methods adequate to the measurement of EDCs in complex environmental matrices (seawater, estuarine and river waters). Also, a complementary effort has been dedicated to both gather all monitoring data and address their potential risk. In this sense, the evaluations done in Portuguese surface waters warned about risks of environmental impacts of oestrogens and can assist the competent authorities to take measures to prevent and clean up these habitats from having EDCs, either by eliminating or at least put them at concentrations below those know to be able to promote biological adverse effects.

The results revealed that the average amounts of oestrogens in Portuguese superficial waters were $\approx 6 \mathrm{ng} / \mathrm{L}$ for $\mathrm{E}_{1}$ and $\approx 10 \mathrm{ng} / \mathrm{L}$ for $\mathrm{E}_{2}$ and $\mathrm{EE}_{2}$. These concentrations, accordingly with the in vivo studies referred previously (section 3.1.1.) are not only able of causing disruptive effects in aquatic animals, but also even induce negative impacts in human health $[25,57]$. The findings become additionally relevant in view of the fact that these habitats are commonly used by residents and/or tourists, both for recreational and fishing purposes.

Analyzing the values of Table 2, and concerning the concentrations of all evaluated oestrogens, it concluded that habitats we studied so far have chemical quality deficiencies. Table 2 also 
points that each analysed geographical zone had quite diverse minimum-maximal amounts. This fact corresponds to spatial differences among sampling sites, in line with the presence/ absence of STPs effluents and domestic discharges in the sampled areas. The last inference is directly correlated with the data obtained in the latest national census, which revealed a high number of houses (over 17,000) without any sort of connection to sewers [58]. Beyond this, there is also an additional factor that is the huge number of tourists that seasonally arrive to several studied zones located in both west and south of the Iberian Peninsula [59,60]. Due to drastic increases of the number of inhabitants, that may rise up to $50 \%$, mainly in summer the concentration of oestrogens in surface waters raised significantly, causing seasonal damages in local biota. So, it becomes clear that the physicochemical parameters typically used to assess the quality of surface waters (i.e., temperature, $\mathrm{pH}$, dissolved $\mathrm{O}_{2}$, nitrites, nitrates and phosphates) are not sufficient to guarantee the protection of both environmental and human health.

Comparing the values compiled in Tables 1 and 2 it is concluded that, in general, the levels of oestrogens tend to be higher in the west Iberian Peninsula than in the rest of central/north Europe. In fact, in average, these substances in the current study area are almost similar to those measured in many Asian countries. Despite this, it is exalted the positive efforts of remediation conducted in some Portuguese environments, such as those produced in the Ave River, considered in the past as one of the most polluted of Europe [61]. There are also commendable the important efforts occurred in the Douro River estuary [62]. In fact, since our first monitoring studies in the last estuary it was possible to observe that the surface waters collected in 2005 [63] contained significantly higher amounts of oestrogens than those collected in 2009, a fact that demonstrates an important improvement of water quality [62]. Unfortunately, because there are no other data prior to 2005, with regard to the levels of $E_{1}, E_{2}$ and $\mathrm{EE}_{2}$ in other Portuguese aquatic systems it is not possible yet to establish with certainty, trend lines relating to a progressive decrease in the concentrations of these EDCs in Portuguese surface waters. In spite of this, other important data provided by our studies demonstrate that: (i) several areas commonly seen as "pristine" (e.g., the Mira River) contain high levels of those oestrogens (unpublished data); (ii) there is an underestimation of the efficacy of the STPs, which at times are not adequately dimensioned, namely for coping with seasonal/touristic influxes; (iii) currents from both Atlantic Ocean and/or estuaries can channel pollutants, such as these oestrogens, towards protected areas (e.g., the natural reserve of the Sado River estuary) [59]. From Table 1 it is observed that also in Spain, particularly in the Ebro River for $\mathrm{EE}_{2}[33,56]$, there are efforts that seem to have been effective in reducing the environmental amounts of these EDCs.

The data repertoire summarized in Table 2 for $E_{1}, E_{2}$, and $E_{2}$ is one of more systematic ones available in the international literature about the oestrogenic status of a particular European country. This information, which can be viewed as a benchmark for the concentrations of oestrogens in Portuguese waters, makes it possible to everybody to monitor the effectiveness of the implementation of measures that may lead to the reduction of environmental levels of those EDCs along the time. 


\begin{tabular}{|c|c|c|c|c|}
\hline EDC & Sampling area & Concentratic & on $(\mathrm{ng} / \mathrm{L})$ & References \\
\hline \multirow{11}{*}{$\mathrm{E}_{1}$} & Lima River estuary and Atlantic coast of Viana-Castelo & 4.6 & -36.3 & [64] \\
\hline & Ave River estuary and Atlantic coast of Vila-Conde & 0.5 & -7.2 & {$[61]$} \\
\hline & Leça River estuary and Atlantic coast of Porto & 4.9 & -10.4 & {$[65]$} \\
\hline & Douro River estuary & $<15$ & -113 & [63] \\
\hline & Douro River estuary and Atlantic coast of Porto & 1.5 & -4.6 & {$[62]$} \\
\hline & Mondego River estuary & & $<5.0$ & [66] \\
\hline & Mondego River and its estuary & 1.0 & -14.6 & [67] \\
\hline & Tagus River and its estuary & $\approx 2$ & $-\approx 6$ & Unpublished \\
\hline & Sado River and its estuary & 1.0 & -9.8 & [59] \\
\hline & Mira River and its estuary & $\approx 3$ & $-\approx 12$ & Unpublished \\
\hline & Ria Formosa & 1.0 & -2.0 & {$[60]$} \\
\hline \multirow{11}{*}{$\mathrm{E}_{2}$} & Lima River estuary and Atlantic coast of Viana-Castelo & 2.4 & -24.4 & {$[64]$} \\
\hline & Ave River estuary and Atlantic coast of Vila-Conde & 1.6 & -9.4 & {$[61]$} \\
\hline & Leça River estuary and Atlantic coast of Porto & 3.3 & -5.9 & {$[65]$} \\
\hline & Douro River estuary & & $<7.0$ & {$[63]$} \\
\hline & Douro River estuary and Atlantic coast of Porto & 5.4 & -8.5 & {$[62]$} \\
\hline & Mondego River estuary & & $<3.0$ & [66] \\
\hline & Mondego River and its estuary & 1.5 & -18.4 & [67] \\
\hline & Tagus River and its estuary & $\approx 3$ & $-\approx 20$ & Unpublished \\
\hline & Sado River and its estuary & 1.2 & -10.8 & [59] \\
\hline & Mira River and its estuary & $\approx 4$ & $-\approx 62$ & Unpublished \\
\hline & Ria Formosa & 1.3 & -10.1 & {$[60]$} \\
\hline \multirow{11}{*}{$\mathrm{EE}_{2}$} & Lima River estuary and Atlantic coast of Viana-Castelo & 0.3 & - 19.4 & {$[64]$} \\
\hline & Ave River estuary and Atlantic coast of Vila-Conde & 0.3 & -20.4 & [61] \\
\hline & Leça River estuary and Atlantic coast of Porto & 2.1 & -4.4 & [65] \\
\hline & Douro River estuary & 18 & -102 & [63] \\
\hline & Douro River estuary and Atlantic coast of Porto & $<1.3$ & -4.5 & {$[62]$} \\
\hline & Mondego River estuary & & $<12$ & {$[66]$} \\
\hline & Mondego River and its estuary & 0.3 & - 11.3 & [67] \\
\hline & Tagus River and its estuary & $\approx 4$ & $-\approx 20$ & Unpublished \\
\hline & Sado River and its estuary & 1.1 & -3.2 & [59] \\
\hline & Mira River and its estuary & $\approx 4$ & $-\approx 67$ & Unpublished \\
\hline & Ria Formosa & 12.1 & -25.0 & {$[60]$} \\
\hline
\end{tabular}

Table 2. Concentrations (minimum-maximum) of natural and pharmaceutical oestrogens in Portuguese surface waters. 


\subsection{Industrial and household products}

\subsubsection{Main characteristics and environmental origins}

There are industrial and household compounds prone to promote oestrogenic effects in wildlife and humans [68-70]. Some of these EDCs are compounds such as phenols (bisphenol A, BPA) and alkylphenols (APs) - viz. octylphenols (OPs) and nonylphenols (NPs) - and their ethoxylates (APEOs) (Figure 2).

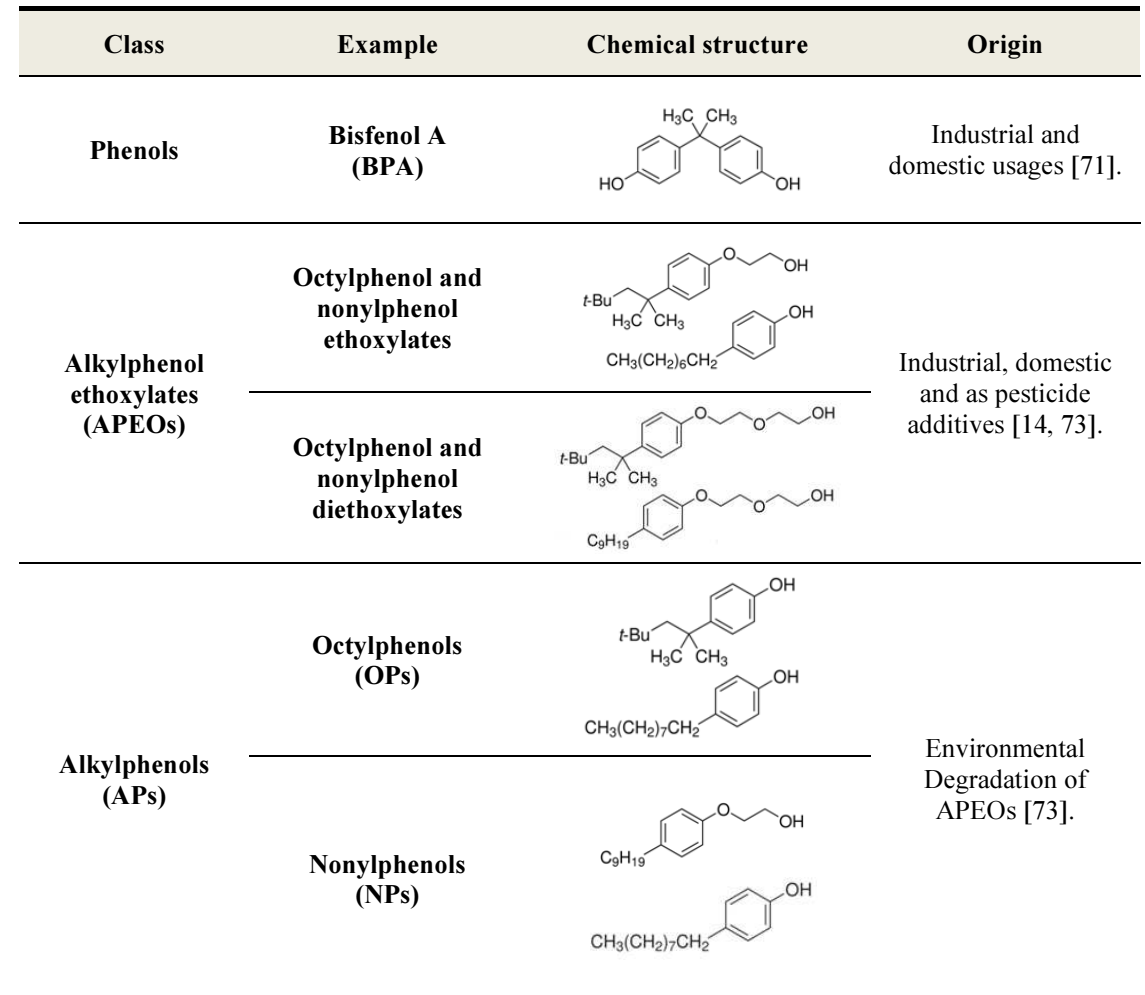

Figure 2. Industrial and household products included in the list of compounds under surveillance by the WFD (European 2013).

Although the disruptive activity of these compounds is much lower than that of natural and synthetic oestrogens, as they may reach levels in the order of tens to hundreds of $\mu \mathrm{g} / \mathrm{L}$ they can became harmful for aquatic fauna. Because of this, and despite great controversy between diverse agents, these compounds become subjected to strict laws that included both APs and APEOs, in the group of "priority substances in the field of water policy 2455/2001/EC" [4]. Presently, the WFD established that the concentration of NPs in surface waters should not exceed $2 \mu \mathrm{g} / \mathrm{L}[6]$. 
BPA origin in the environment comes from the fact that it is the monomer of the polycarbonate (plastic) used in an huge variety of domestic stuffs and as an intermediate in the synthesis of epoxy resins, flame retardants and many other products [71]. In spite of its vast usage, controversial opinions do exist among those calling for its banning and those that devaluate the BPA toxic effects in realistic scenarios. The February 2007 study "Toxic Baby Bottle's", by the Environment California Research and Policy Center [72], showed that even small amounts of BPA may be one cause of diseases, including breast cancer, prostatic hyperplasia, diabetes, obesity, and hyperactivity disorders involving the immune system. Infertility and early puberty are also among the possible effects caused by BPA, and all of them are associated with the compound's ability to deregulate the endocrine system.

The APEOs sources in the environment are due to their commonly usage as non-ionic surfactant compounds and dispersants [14,73]. Due to these properties APEOs are being used in detergents and additives of pesticide formulations. Currently, these applications are prohibited in the EU [4] as these compounds are known to readily degrade, in both aerobic and anaerobic conditions, into APs that are more toxic compounds than APEOs (Figure 3). In spite of the APs toxicity, it is known that their lifetime is not long, since they usually degrade in about 10 to 15 hours after sunlight exposure [74]. Thus, it is concluded that the ubiquitous presence of APs in surface waters implies the continuous entrance of APEOs in the environment [60].<smiles>[R]c1ccc(OCC)cc1</smiles>

Alkylphenol Ethoxylate

$\left(\mathrm{AP}_{\mathrm{n}} \mathrm{EO} n=0-20\right)$
Alkylphenol Monoethoxylate

$\left(\mathrm{AP}_{1} \mathrm{EO}\right)$
Alkylphenol

(AP)

Figure 3. Summarized degradation mechanism of APEOs in the environment adapted from Warhurst [75].

The endocrine disrupting activity of APEOs and (especially) that of APs, whether they are octylphenols (4-OP and 4-t-OP) or nonylphenols (4-NP and 4-n-NP) is derived from the existence of similarities between the structure of these compounds and that of $\mathrm{E}_{2}$ (Figure 4) [76].

(a)

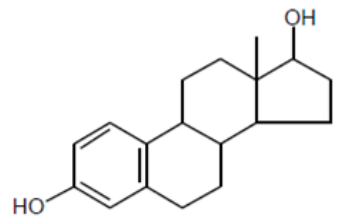

(b)<smiles>CC(C)CC(C)CC(C)c1ccc(O)cc1</smiles>

Figure 4. Comparison between the chemical structures of $\mathrm{E}_{2}(\mathbf{a})$ and 4-NP (b). 
As such, APs may induce oestrogenic effects using the same paths described in Section 3. These effects were proved, for example, after in vivo exposures of male rainbow trout (Oncorhynchus mykiss) to $30 \mu \mathrm{g} / \mathrm{L}$ of $4-\mathrm{OP}$, and of male Japanese medaka (O. latipes) to $30 \mu \mathrm{g} / \mathrm{L}$ of $4-\mathrm{NP}$, eliciting, respectively, an inhibition of the testicular growth and hermaphroditism [27, 77, 78]. Alas, as it is possible to purchase in EU countries imported products containing APEOs - see an interesting record in "APEOs Investigation Report" [79] - these EDCs continue to exist in European surface waters.

Currently, we theorize that the most likely source of APEOs in the aquatic systems is the discharge of wastewater effluents from STPs, nevertheless not neglecting the possible leaching caused by the runoff of these EDCs from landfills and agricultural areas (as APEOs are emulsifiers in some pesticide formulations).

\subsection{2. $B P A, A P E O$ s and $A P s$ in surface waters}

Table 3 shows an overview of BPA, APEOs and APs in estuaries and rivers worldwide. In line with the broad use of these EDCs it is observed that, at least up to 2005, their concentrations in surface waters were in the order of $\mu \mathrm{g} / \mathrm{L}$. For instance, ten years ago BPA reached concentrations of $5.0 \mu \mathrm{g} / \mathrm{L}$ in several German rivers [80] and the alkylphenols, 4-OP and 4-NP, levels attained 26 to $37 \mu \mathrm{g} / \mathrm{L}$ in several Spanish rivers and estuaries [81]. In line with these observations, it could be hypothesized that if there was not the pressure exerted by the program set out by the WFD, together with the directive 76/769/EEC [82] that established restrictions on the marketing and use of NPs and NPEOs, the current environmental content of these EDCs in European surface waters would probably be worse than that found nowadays. It is important to stress that the last directive advocates the banishment of NP and NPEOs in formulations when their levels are equal or higher than $0.1 \%$ by mass. This measure leaded to a decrease in the use of NPEOs or even their deliberate discontinuity in Europe (case of Germany) and, consequently, the number of studies that accompanied the temporal evolution of these compounds began decreasing. This aspect increases the difficulty to assess the actual amounts of APEOs and APs in European surface waters, being assumed that their usage was deprecated; a presumption that is not entirely correct, as we have been witnessing.

As shown in Table 3, the levels of APs in several EU countries continue to show potential toxicity $(<0.5-37,300 \mathrm{ng} / \mathrm{L})$. This poses obstacles to the compliance defined by WFD, since it seems impossible to achieve concentrations of $\leq 100 \mathrm{ng} / \mathrm{L}$ for the OPs and, $\leq 300 \mathrm{ng} / \mathrm{L}$ for NPs, in all EU states up to 2015. However, it is possible to observe that recent studies revealed that there is positive effort towards the reduction of the global amounts of both APs and BPA in all European countries. So, presently, and also accordingly to the compilation in Table 3, it is observed that in general the levels of APs and BPA are generally higher in Asia and South America than those measured in the EU.

In opposition, and with the exception of the two works [83, 84], before 2005 there were virtually no data about the levels of these EDCs in the west Iberian Peninsula, inc. Portuguese surface waters. These observations leaded to the creation of regular monitoring programs for these compounds, in order to make a general assessment of the situation in various locations and, when possible, monitor their evolution in time. Such temporal results are central to define if 
the implementation of WFD policies are being successful in the field, alone or together and correlated with biologic outputs (e.g., biomarkers data). The efforts done in the last decade for evaluating BPA, APEOs and APs pollution in Portuguese surface waters from estuaries, rivers and coastal waters are compiled in Table 4.

\begin{tabular}{|c|c|c|c|c|}
\hline \multirow[t]{2}{*}{ EDC } & \multirow{2}{*}{$\begin{array}{l}\text { Sampling area } \\
\text { Gulf of Gdansk, Poland }\end{array}$} & \multicolumn{2}{|c|}{ Concentration (ng/L) } & \multirow{2}{*}{$\begin{array}{l}\text { References } \\
{[85]}\end{array}$} \\
\hline & & 26.9 & - 48.1 & \\
\hline & Estuaries and rivers, The Netherlands & $<8.8$ & - 1,000 & [40] \\
\hline & German Rivers & 0.5 & -14 & [86] \\
\hline & Elbe River and its tributaries, Germany & 3.8 & - 92.0 & {$[80]$} \\
\hline & Coastal area of Baltic Sea, Germany & ND & -5.7 & {$[42]$} \\
\hline & Baden-Württemberg Rivers, Germany & $<50$ & -272 & [87] \\
\hline & Glatt River, Switzerland & 9.0 & -76 & {$[88]$} \\
\hline & Sussex River, England & $<5.3$ & -10 & [89] \\
\hline & Ebro River, Spain & 10 & -20 & [33] \\
\hline & Ebro River, Spain & ND & - 61 & {$[56]$} \\
\hline & Llobregat, Cardener, Anoia, Riera de Rubi River, Spain & $<90$ & $-2,970$ & {$[81]$} \\
\hline & Venice Lagoon, Italy & $<1.0$ & -145 & {$[34]$} \\
\hline \multirow[t]{13}{*}{ BPA } & Thermaikos Gulf, Nothern Aegean Sea, Greece & 10.6 & -52.3 & [47] \\
\hline & New Orleans Waters,USA & 0.9 & -158 & [90] \\
\hline & South Florida, USA & 4.8 & -32 & {$[50]$} \\
\hline & Brazilian surface water & 25 & -84 & {$[51]$} \\
\hline & Coastal waters of Shenzhen, China & 11.2 & -776.6 & [91] \\
\hline & Dianchi Lake, China & 35 & - 1,081 & [92] \\
\hline & Liao River, China & 12.3 & -116.5 & [52] \\
\hline & Songhua River, Northern China & 8.24 & -263 & {$[54]$} \\
\hline & Pearl rivers, South China & 4.35 & - 1,390 & {$[31,32]$} \\
\hline & Yangtze River estuary, China & 0.98 & - 43.8 & [53] \\
\hline & River waters of South Korea and seven Asian countries & 3.0 & -100 & [93] \\
\hline & Tama River, Japan & 4.8 & -76.3 & [29] \\
\hline & Coastal waters, Singapore & ND & $-2,470$ & {$[94]$} \\
\hline \multirow{4}{*}{ OPs } & Gulf of Gdansk, Poland & $<5.0$ & - 65.9 & [85] \\
\hline & Estuaries and rivers, The Netherlands & $<50$ & $-6,300$ & [40] \\
\hline & German Rivers & 0.8 & -54 & [86] \\
\hline & Baden-Württemberg River, Germany & $<20$ & -189 & [87] \\
\hline
\end{tabular}




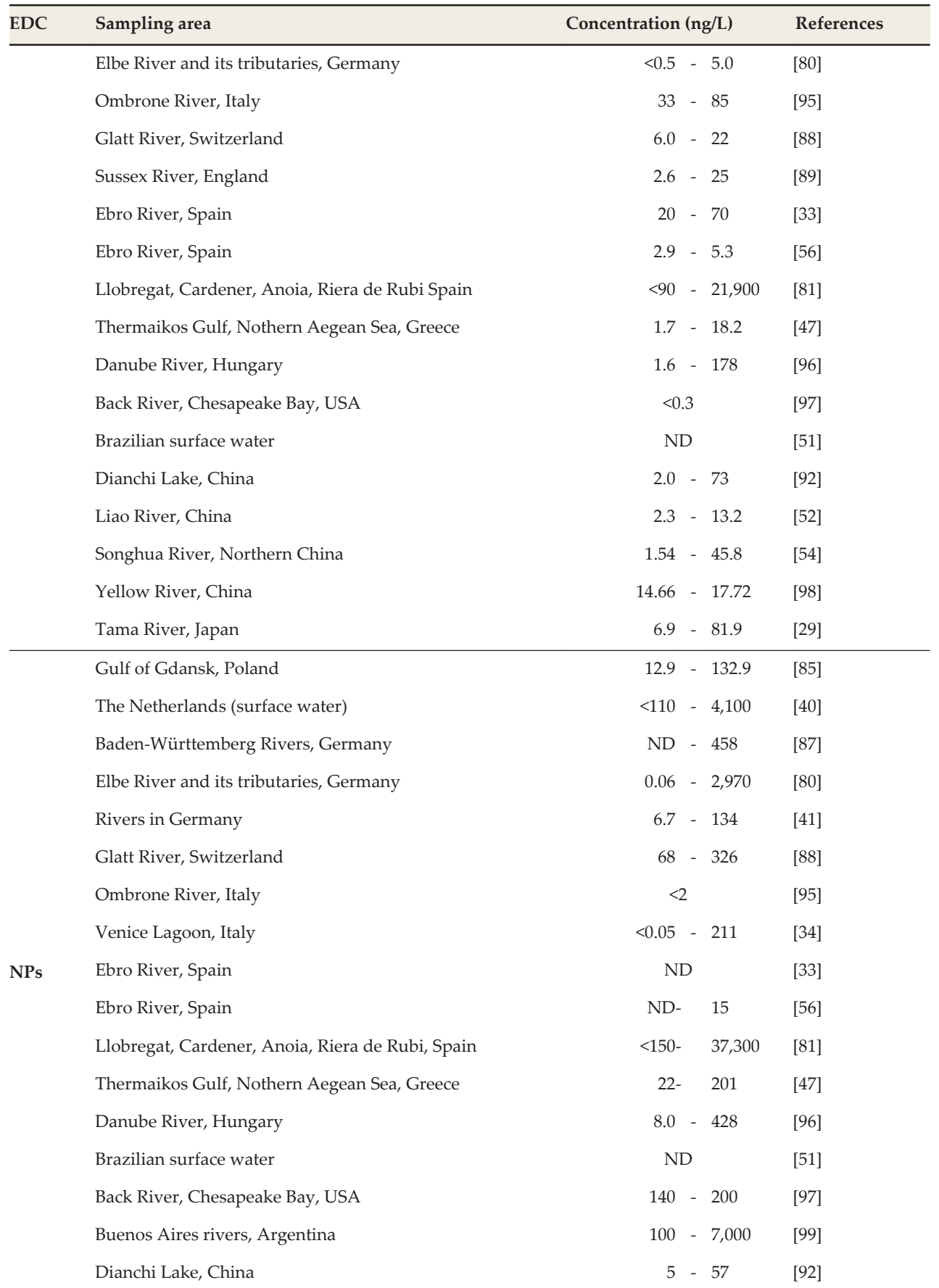




\begin{tabular}{|c|c|c|c|c|}
\hline \multirow[t]{8}{*}{ EDC } & \multirow{2}{*}{$\begin{array}{l}\text { Sampling area } \\
\text { Liao River, China }\end{array}$} & \multicolumn{2}{|c|}{ Concentration (ng/L) } & \multirow{2}{*}{$\begin{array}{l}\text { References } \\
{[52]}\end{array}$} \\
\hline & & 112 & - 900.7 & \\
\hline & Songhua River, Northern China (4-t-NP) & 106 & -344 & [54] \\
\hline & Songhua River, Northern China (4-n-NP) & 0.35 & -3.77 & [54] \\
\hline & Area of Chongqing, China & 100 & - 7,300 & [100] \\
\hline & Pearl River, China & 36 & $-33,000$ & [31] \\
\hline & Tama River, Japan & 51.6 & - 147.0 & [29] \\
\hline & River waters of South Korea and 7 Asian Countries & $<\mathrm{LOD}$ & $-2,097$ & [93] \\
\hline \multirow{9}{*}{ OPEOs } & The Netherlands (surface water) & $<160$ & - 1,700 & [40] \\
\hline & Elbe River and its tributaries, Germany & 0.6 & -9.6 & [80] \\
\hline & Seine River, France & 55 & -63 & [101] \\
\hline & Ombrone River, Italy (4-t-OP $\left.{ }_{1} \mathrm{EO}\right)$ & \multicolumn{2}{|c|}{$<94$} & [95] \\
\hline & Ombrone River, Italy (4-t-OP $2 \mathrm{EO}$ ) & \multicolumn{2}{|c|}{$6-34$} & [95] \\
\hline & Ebro River, Spain $\left(\mathrm{OP}_{2} \mathrm{EO}\right)$ & $1.7-$ & -8.3 & [56] \\
\hline & Thermaikos Gulf, Greece $\left(\mathrm{OP}_{1} \mathrm{EO}\right)$ & \multicolumn{2}{|c|}{$<4-9.5$} & [47] \\
\hline & Thermaikos Gulf, Greece $\left(\mathrm{OP}_{2} \mathrm{EO}\right)$ & \multicolumn{2}{|c|}{$<4-11.7$} & [47] \\
\hline & Estuaries and rivers, USA & \multicolumn{2}{|r|}{ - 400} & {$[102]$} \\
\hline \multirow{17}{*}{ NPEOs } & Back River, Chesapeake Bay, USA $\left(\mathrm{OP}_{1} \mathrm{EO}\right)$ & \multicolumn{2}{|c|}{$<0.2$} & [97] \\
\hline & Back River, Chesapeake Bay, USA $\left(\mathrm{OP}_{2} \mathrm{EO}\right)$ & \multicolumn{2}{|c|}{$<0.02$} & [97] \\
\hline & The Netherlands (surface water) & $<180$ & $-8,700$ & [40] \\
\hline & Elbe River and its tributaries, Germany & $<0.5$ & -124 & [80] \\
\hline & Seine River, France $\left(\mathrm{NP}_{1} \mathrm{EO}\right)$ & 9 & -11 & [101] \\
\hline & Ombrone River, Italy (4-t-NP $\mathrm{NO}_{1}$ ) & \multicolumn{2}{|c|}{$<122$} & [95] \\
\hline & Ombrone River, Italy (4-t-NP${ }_{2} \mathrm{EO}$ ) & \multicolumn{2}{|c|}{$9-35$} & [95] \\
\hline & Ebro River, Spain $\left(\mathrm{NP}_{2} \mathrm{EO}\right)$ & \multicolumn{2}{|c|}{$9.4-275$} & [56] \\
\hline & Thermaikos Gulf, Greece $\left(\mathrm{NP}_{1} \mathrm{EO}\right)$ & \multicolumn{2}{|c|}{$15.2-270$} & [47] \\
\hline & Thermaikos Gulf, Greece $\left(\mathrm{NP}_{2} \mathrm{EO}\right)$ & \multicolumn{2}{|c|}{$14.6-346$} & [47] \\
\hline & Estuaries and rivers, USA & $220-$ & - 1,050 & [102] \\
\hline & Back River, Chesapeake Bay, USA $\left(\mathrm{NP}_{1} \mathrm{EO}\right)$ & $<0.2$ & -67 & [97] \\
\hline & Back River, Chesapeake Bay, USA $\left(\mathrm{NP}_{2} \mathrm{EO}\right)$ & 12 & -57 & [97] \\
\hline & Buenos Aires, Argentina $\left(\mathrm{NP}_{1} \mathrm{EO}\right)$ & 100 & - 9,200 & [99] \\
\hline & Buenos Aires, Argentina $\left(\mathrm{NP}_{2} \mathrm{EO}\right)$ & 100 & $-5,400$ & [99] \\
\hline & Songhua River, Northeastern China $\left(\mathrm{NP}_{1} \mathrm{EO}\right)$ & $8.9-$ & -385 & [54] \\
\hline & Songhua River, Northeastern China ( $\left.\mathrm{NP}_{2} \mathrm{EO}\right)$ & 19.6 & -321 & [54] \\
\hline
\end{tabular}




\begin{tabular}{llrll}
\hline EDC & Sampling area & Concentration $(\mathrm{ng} / \mathrm{L})$ & \multicolumn{2}{c}{ References } \\
\hline Dianchi Lake, China $\left(\mathrm{NP}_{1} \mathrm{EO}\right)$ & $54-1,942$ & {$[92]$} \\
Dianchi Lake, China $\left(\mathrm{NP}_{2} \mathrm{EO}\right)$ & $98-2,074$ & {$[92]$} \\
\hline
\end{tabular}

ND: Not Detected. LOD: Limit of Detection.

Table 3. Concentrations (minimum-maximum) of industrial and household products in surface waters worldwide.

\subsubsection{BPA, APEOs and APs in west Iberian Peninsula surface waters}

Recent studies revealed that surface waters taken from Portuguese aquatic environments show average concentrations of $650 \mathrm{ng} / \mathrm{L}$ for BPA, 1,000 ng/L for APEOs and $360 \mathrm{ng} / \mathrm{L}$ for APs (Table 4). Comparing such data with those reported in other countries (Table 3) it is observed that in Portugal the global amounts of these compounds are still quite high. Nevertheless, it is important to note that the values measured before/during 2005 [63, 66, 83, 84], namely for BPA and APs, are significantly higher than those measured in 2010-2011. Thus, and assuming that these results represent the wider reality of the west Iberian Peninsula, it seems that good efforts are being done to reduce the levels of industrial and household pollution (Table 4). In spite of this, Table 4 shows that APEOs exist in amounts that are still approximately one hundred fold higher than those recommended by the European legislation. These observations may be due to the presence of several textile industries and also large agricultural fields located near the sampling areas (Table 4); it should be noticed that several pesticide formulations use APEOs as dispersants. However, since similar amounts of APEOs were found in the Spanish and Greek waters $[68,69]$ it is possible that these EDCs are still being used, and therefore constitute a global problem of coastal areas.

\begin{tabular}{|c|c|c|c|}
\hline EDC & Sampling area & Concentration (ng/L) & References \\
\hline \multirow{14}{*}{ BPA } & Lima River estuary and Atlantic coast of Viana-Castelo & $1.9-35.7$ & {$[64]$} \\
\hline & Ave River estuary and Atlantic coast of Vila-Conde & $7.9-521.8$ & [61] \\
\hline & Leça River estuary and Atlantic coast of Porto & $30.6-62.4$ & [65] \\
\hline & Douro River estuary & $<80-10,700$ & {$[63]$} \\
\hline & Douro River estuary and Atlantic coast of Porto & $20.4-314.0$ & [62] \\
\hline & Mondego River estuary & $<6.6-880$ & [66] \\
\hline & Mondego River and its estuary & $8.5-184.6$ & [67] \\
\hline & Tagus River estuary & $\approx 13-\approx 320$ & Unpublished \\
\hline & Sado River estuary & $7.3-28$ & [103] \\
\hline & Sado River estuary & $12.2-28.9$ & [59] \\
\hline & Mira River and its estuary & $\approx 7-\approx 360$ & Unpublished \\
\hline & Ria Formosa & $6.5-71.7$ & {$[60]$} \\
\hline & Portuguese rivers and estuaries & $200-4,000$ & [83] \\
\hline & Portuguese rivers and estuaries & $0.2-5,000$ & [84] \\
\hline 4-OP & Lima River estuary and Atlantic coast of Viana-Castelo & $6.2-86.5$ & [64] \\
\hline
\end{tabular}




\begin{tabular}{|c|c|c|c|c|}
\hline \multirow[t]{10}{*}{ EDC } & \multirow{2}{*}{$\begin{array}{l}\text { Sampling area } \\
\text { Ave River estuary and Atlantic coast of Vila-Conde }\end{array}$} & \multicolumn{2}{|c|}{ Concentration (ng/L) } & \multirow{2}{*}{$\frac{\text { References }}{[61]}$} \\
\hline & & 0.6 & -8.3 & \\
\hline & Leça River estuary and Atlantic coast of Porto & 27.0 & - 68.3 & [65] \\
\hline & Douro River estuary and Atlantic coast of Porto & & $<3.5$ & {$[62]$} \\
\hline & Mondego River and its estuary & 0.7 & $-1,279$ & [67] \\
\hline & Tagus River and its estuary & $\approx 6$ & $-\approx 150$ & Unpublished \\
\hline & Sado River estuary & 2.8 & -27.8 & [59] \\
\hline & Mira River and its estuary & $\approx 6$ & $-\approx 28$ & Unpublished \\
\hline & Ria Formosa & 3.5 & -8.5 & {$[60]$} \\
\hline & Portuguese rivers and estuaries & 0.1 & $-30,000$ & [84] \\
\hline \multirow{9}{*}{ 4-t-OP } & Lima River estuary and Atlantic coast of Viana-Castelo & 5.7 & -105.0 & [64] \\
\hline & Ave River estuary and Atlantic coast of Vila-Conde & 1.3 & -25.4 & [61] \\
\hline & Leça River estuary and Atlantic coast of Porto & 7.9 & -60.0 & [65] \\
\hline & Douro River estuary and Atlantic coast of Porto & 5.1 & -30.6 & [62] \\
\hline & Mondego River and its estuary & 30 & $-27,502$ & [67] \\
\hline & Tagus River and its estuary & $\approx 2$ & $-\approx 71$ & Unpublished \\
\hline & Sado River and its estuary & 11.4 & -22.0 & [59] \\
\hline & Mira River and its estuary & $\approx 4$ & $-\approx 27$ & Unpublished \\
\hline & Ria Formosa & 4.3 & - 40.9 & {$[60]$} \\
\hline \multirow{9}{*}{ 4-n-NP } & Lima River estuary and Atlantic coast of V. Castelo & 3.0 & -35.4 & {$[64]$} \\
\hline & Ave River estuary and Atlantic coast of V. Conde & 0.3 & -16.8 & [61] \\
\hline & Leça River estuary and Atlantic coast of Porto (north) & 28.8 & - 63.5 & [65] \\
\hline & Douro River estuary and Atlantic coast of Porto & 3.3 & -116.0 & {$[62]$} \\
\hline & Mondego River and its estuary & 20.8 & $-2,770$ & [67] \\
\hline & Tagus River and its estuary & $\approx 1$ & $-\approx 41$ & Unpublished \\
\hline & Sado River estuary & 2.6 & -27.3 & [59] \\
\hline & Mira River and its estuary & $\approx 2$ & $-\approx 33$ & Unpublished \\
\hline & Ria Formosa & 3.4 & - 14.6 & {$[60]$} \\
\hline \multirow{10}{*}{ 4-NP } & Lima River estuary and Atlantic coast of Viana-Castelo & 3.9 & - 649.8 & {$[64]$} \\
\hline & Ave River estuary and Atlantic coast of Vila-Conde & 43.3 & -154.9 & {$[61]$} \\
\hline & Douro River estuary and Atlantic coast of Porto & 88.2 & -170.0 & {$[62]$} \\
\hline & Mondego River and its estuary & 80.6 & $-1,003$ & [67] \\
\hline & Tagus River and its estuary & $\approx 200$ & $-\approx 1,600$ & Unpublished \\
\hline & Sado River estuary & 129.2 & -239.9 & [59] \\
\hline & Mira River and its estuary & $\approx 52$ & $-\approx 289$ & Unpublished \\
\hline & Ria Formosa & 12.2 & -546.6 & {$[60]$} \\
\hline & Portuguese rivers and estuaries & 200 & $-30,000$ & [83] \\
\hline & Portuguese rivers and estuaries & 0.3 & $-25,000$ & [84] \\
\hline
\end{tabular}




\begin{tabular}{|c|c|c|c|c|}
\hline EDC & Sampling area & Concentratic & on $(\mathrm{ng} / \mathrm{L})$ & References \\
\hline \multirow{9}{*}{$\mathrm{OP}_{1} \mathrm{EO}$} & Lima River estuary and Atlantic coast of Viana-Castelo & 8.8 & -125.0 & [64] \\
\hline & Ave River estuary and Atlantic coast of Vila-Conde & 2.3 & -31.7 & [61] \\
\hline & Leça River estuary and Atlantic coast of Porto & 20.8 & -72.9 & [65] \\
\hline & Douro River estuary and Atlantic coast of Porto & 33.0 & - 60.0 & [62] \\
\hline & Mondego River and its estuary & 10.7 & $-2,337$ & [67] \\
\hline & Tagus River and its estuary & $\approx 6$ & $-\approx 142$ & Unpublished \\
\hline & Sado River estuary & 13.0 & - 109.4 & [59] \\
\hline & Mira River and its estuary & $\approx 9$ & $-\approx 63$ & Unpublished \\
\hline & Ria Formosa & 6.9 & -35.6 & {$[60]$} \\
\hline \multirow{9}{*}{$\mathrm{OP}_{2} \mathrm{EO}$} & Lima River estuary and Atlantic coast of Viana-Castelo & 21.5 & -374.0 & [64] \\
\hline & Ave River estuary and Atlantic coast of Vila-Conde & 44.1 & - 208.7 & [61] \\
\hline & Leça River estuary and Atlantic coast of Porto & 29.7 & -213.2 & [65] \\
\hline & Douro River estuary and Atlantic coast of Porto & 100.0 & - 424.0 & {$[62]$} \\
\hline & Mondego River and its estuary & 21.5 & $-2,330$ & [67] \\
\hline & Tagus River and its estuary & $\approx 4$ & $-\approx 67$ & Unpublished \\
\hline & Sado River and its estuary & 60.0 & -384.2 & [59] \\
\hline & Mira River and its estuary & $\approx 4$ & $-\approx 43$ & Unpublished \\
\hline & Ria Formosa & 46.5 & -182.1 & {$[60]$} \\
\hline \multirow{9}{*}{$\mathrm{NP}_{1} \mathrm{EO}$} & Lima River estuary and Atlantic coast of Viana-Castelo & 44.9 & -259.1 & {$[64]$} \\
\hline & Ave River estuary and Atlantic coast of Vila-Conde & 29.9 & -227.8 & [61] \\
\hline & Leça River estuary and Atlantic coast of Porto & 115.6 & -923.3 & [65] \\
\hline & Douro River estuary and Atlantic coast of Porto & 101.0 & -354.0 & {$[62]$} \\
\hline & Mondego River and its estuary & 95.4 & - 7,794 & [67] \\
\hline & Tagus River and its estuary & $\approx 15$ & $-\approx 340$ & Unpublished \\
\hline & Sado River and its estuary & 60.0 & -311.4 & [59] \\
\hline & Mira River and its estuary & $\approx 14$ & $-\approx 816$ & Unpublished \\
\hline & Ria Formosa & 41.4 & - 278.9 & {$[60]$} \\
\hline \multirow{9}{*}{$\mathrm{NP}_{2} \mathrm{EO}$} & Lima River estuary and Atlantic coast of Viana-Castelo & 47.3 & - 467.0 & {$[64]$} \\
\hline & Ave River estuary and Atlantic coast of Vila-Conde & 142.6 & -750.6 & [61] \\
\hline & Leça River estuary and Atlantic coast of Porto & 723.1 & $-2,132$ & [65] \\
\hline & Douro River estuary and Atlantic coast of Porto & 212.0 & $-1,148$ & {$[62]$} \\
\hline & Mondego River and its estuary & 118.5 & - 18,327 & [67] \\
\hline & Tagus River and its estuary & $\approx 40$ & $-\approx 300$ & Unpublished \\
\hline & Sado River and its estuary & 167.0 & - 1,096 & [59] \\
\hline & Mira River and its estuary & $\approx 111$ & $-\approx 3,600$ & Unpublished \\
\hline & Ria Formosa & 49.1 & - 779.7 & [60] \\
\hline
\end{tabular}

Table 4. Concentrations (minimum-maximum) of industrial and household products in Portuguese surface waters. 


\subsection{Naturally occurring compounds present in plants}

\subsubsection{Phytoestrogens, characteristics and their environmental origin}

Accordingly to the U.S. Food Standards Agency [104], phytoestrogens are "any compound of vegetable origin, or their(s) metabolite(s) with structural similarities to $E_{2}$, which results in their ability to mimic or block the action of the endogenous sexual hormone in Man". Phytoestrogens fall into two classes: (i) flavonoids; and (ii) non-flavonoids. The flavonoids are subdivided into the three subclasses: (i) isoflavones (Figure 5); (ii) coumestans; and (iii) prenylflavonoids. The non-flavonoids include the lignans [104].

Isoflavone
$\begin{gathered}\text { Formononetin } \\ \text { (FORM) }\end{gathered}$
(BOAIO)
(BIO-A)

Figure 5. Phytoestrogens with potential oestrogenic activity.

In this Chapter it is focused the group of isoflavones, which include compounds such as daidzein (DAID), genistein (GEN), biochanin A (BIO-A) and formononetin (FORM), due to their structural resemblance with $\mathrm{E}_{2}$. Although not steroids, isoflavones exhibit high affinity for oestrogen receptors. In fact, both in vivo and in vitro studies have demonstrated their ability to induce abnormal liver synthesis of vitellogenin in male goldfish (Carassius auratus) and in rainbow trout (O. mykiss) [106-108], and the triggering of hermaphroditism in fish, such as the Japanese medaka (O. latipes) exposed to $1,000 \mu \mathrm{g} / \mathrm{L}$ of GEN [15]. Thus, although these compounds have not been included yet in the list of substances under the supervision by the WFD, but because their global levels in superficial waters can easily reach levels 1,000 times higher than those of $E_{2}$, i.e., in the order of $\mu \mathrm{g} / \mathrm{L}$ or even $\mathrm{mg} / \mathrm{L}$, it is plausible to think that phytoestrogens may induce effects equivalent to those described for $\mathrm{E}_{2}$ in spite of having a much lower potency [109]. Despite this, there are not many studies dedicated to the evaluation of these EDCs in surface waters. Also, little information exists about their origins and persistence. Presently, the main source of phytoestrogens in the aquatic environment is attributed either 
to the presence of the seagrass Zostera noltii, and/or to the leaching from the margins where plants rich in these compounds may exist, e.g., Typha spp., Phragmites communis, Juncus acutus, Fuirena pubescens, Carex riparia and Carex hispida, Cladium mariscus, Callitriche stagnalis and Potamogeton spp., Trifolium spp. and Papilionaceae [110-112].

Other equally important source of phytoestrogens in surface waters is their disposal as a result of industrial processes - especially in food processing industries and paper mills [105]. So, as the water levels of these compounds can quickly mount up to $\mathrm{mg} / \mathrm{L}$, it is possible that they exert in the wilderness the disruptive biological effects attributed to them [112-114]. Nonetheless, if the levels of these EDCs do not surpass $\mathrm{ng} / \mathrm{L}$ and, in the absence of other potentially stressful compounds, it is most likely that phytoestrogens are harmless [115].

\subsubsection{Phytoestrogens in surface waters}

Comparatively to the other EDCs, the evaluation of phytoestrogens in aquatic environments, particularly in surface waters of estuaries or rivers, in less studied than the other EDCs referred in this Chapter. This is an important gap in the current knowledge since one the possible origins of these compounds is the natural aquatic flora, which generally is very developed in areas where the organic load is high and prone for eutrophication [116], which is a banal occurrence worldwide. In Table 5 it is shown a collection of studies done in several continents, and the data reveal that the highest concentrations of DAID (42,900 ng/L) and GEN (143,000 n/L) were found in Asia, in the Japanese Kanzaki River. In contrast, the highest amounts of FORM (157 $\mathrm{ng} / \mathrm{L}$ ) and BIO-A (59.4 ng/L) were measured in Europe, at various locations in Switzerland.

\begin{tabular}{|c|c|c|c|c|}
\hline \multirow[t]{2}{*}{ EDC } & \multirow{2}{*}{$\begin{array}{l}\text { Sampling area } \\
\text { Tiber River, Italy }\end{array}$} & \multicolumn{2}{|c|}{ Concentration (ng/L) } & \multirow{2}{*}{$\begin{array}{l}\text { References } \\
{[44]}\end{array}$} \\
\hline & & 2.0 & -3.0 & \\
\hline & Glatt, Töss, Swiss Midlands, Switzerland & ND & 31.5 & [117] \\
\hline & Surface waters, Switzerland & $\mathrm{De}$ & ected & [118] \\
\hline & Drainage waters, Switzerland & 5.0 & -30 & [118] \\
\hline & Rhine River, Germany & & 10 & [119] \\
\hline & Several rivers, Iowa, USA & 10.5 & 41 & [120] \\
\hline & Lake Vadnais and Metro Plant effluent channel, USA & 1.6 & 1.8 & [115] \\
\hline \multirow[t]{10}{*}{ DAID } & Straight Lake, USA & \multicolumn{2}{|c|}{ ND } & [115] \\
\hline & Several Rivers, Brazil & 36.2 & 276 & [121] \\
\hline & Waters from Mullet Creek, Australia & 3.0 & 7.0 & [122] \\
\hline & Macquarie Rivulet River, Australia & 14 & 33 & [122] \\
\hline & Mullet Creek water, Australia & 2.0 & -12 & [122] \\
\hline & Toolijooa surface dam (water), Australia & ND & 120 & [122] \\
\hline & Kanzaki River, Japan & LOD & 42,900 & [123] \\
\hline & Zhangcun River, China & ND & 1,490 & [124] \\
\hline & Tiber River, Italy & 4.0 & 7.0 & [44] \\
\hline & Glatt, Töss, Swiss Midlands, Switzerland & ND & $-\quad 24.2$ & [117] \\
\hline \multirow[t]{3}{*}{ GEN } & Surface waters, Switzerland & \multicolumn{2}{|c|}{ ND } & [118] \\
\hline & Drainage waters, Switzerland & Detected & 14 & [118] \\
\hline & Several rivers, Iowa, USA & ND & 8.0 & {$[120]$} \\
\hline
\end{tabular}




\begin{tabular}{|c|c|c|c|c|}
\hline \multirow[t]{2}{*}{ EDC } & \multirow{2}{*}{$\begin{array}{l}\text { Sampling area } \\
\text { Waters from Upper Midwest (USA) }\end{array}$} & \multicolumn{2}{|c|}{ Concentration (ng/L) } & \multirow{2}{*}{$\begin{array}{l}\text { References } \\
{[115]}\end{array}$} \\
\hline & & 1.4 & 1.6 & \\
\hline & Straight Lake, USA & \multicolumn{2}{|l|}{ ND } & [115] \\
\hline & Several Rivers, Brazil & $3.96-$ & 336 & [122] \\
\hline & Waters from Mullet Creek, Australia & ND & 1.0 & [122] \\
\hline & Macquarie Rivulet River, Australia & 1.0 & 8.0 & [122] \\
\hline & Toolijooa surface dam (water), Australia & 1.0 & 20 & [122] \\
\hline & Yeongsan and Seomjin Rivers, Korea & ND & 0.7 & [93] \\
\hline & Salut, Malaysia & \multicolumn{2}{|l|}{ ND } & [93] \\
\hline & Khong River, Thailand & \multicolumn{2}{|l|}{ ND } & [93] \\
\hline & Long Xuyen city, Vietnam & 1.5 & 2.4 & [93] \\
\hline & Siem Reap, Cambodia & \multicolumn{2}{|l|}{4.4} & [93] \\
\hline & Fenhe, China & 3.6 & 5.0 & [93] \\
\hline & Zhangcun River, China & ND & 2,650 & [124] \\
\hline & Kanzaki River (Japan) & LOD & 143,000 & [123] \\
\hline \multirow{10}{*}{ FORM } & Tiber River, Italy & \multicolumn{2}{|l|}{ ND } & {$[44]$} \\
\hline & Glatt, Töss, Swiss Midlands, Switzerland & ND & 217 & [117] \\
\hline & Surface waters, Switzerland & Detected & 21 & [118] \\
\hline & Drainage waters, Switzerland & 44 & 157 & [118] \\
\hline & Several rivers, Iowa, USA & 5.3 & 13.5 & [120] \\
\hline & Straight Lake, USA & \multicolumn{2}{|l|}{ ND } & [115] \\
\hline & Lake Vadnais, USA & 0.9 & 1.1 & [115] \\
\hline & Macquarie Rivulet River, Australia & ND & 2.0 & [122] \\
\hline & Waters from Mullet Creek, Australia & ND & 1.0 & {$[122]$} \\
\hline & Toolijooa surface dam (water), Australia & ND & 35 & {$[122]$} \\
\hline \multirow{10}{*}{ BIO-A } & Tiber River, Italy & 1.0 & 3.0 & [44] \\
\hline & Glatt, Töss, Swiss Midlands, Switzerland & ND & 59.4 & [117] \\
\hline & Surface waters, Switzerland & Detected & 12 & [118] \\
\hline & Drainage waters, Switzerland & 7 & 22 & [118] \\
\hline & Several rivers, Iowa, USA & 1.7 & 5.6 & [120] \\
\hline & Lake Vadnais and Metro Plant effluent channel, USA & ND & 1.1 & [115] \\
\hline & Straight Lake, USA & \multicolumn{2}{|l|}{ ND } & [115] \\
\hline & Waters from Mullet Creek, Australia & ND & 0.1 & [122] \\
\hline & Macquarie Rivulet River, Australia & ND & 1.0 & [122] \\
\hline & Toolijooa surface dam (water), Australia & ND & 4.0 & [122] \\
\hline
\end{tabular}

ND: Not Detected. LOD: Limit of Detection.

Table 5. Concentrations (minimum-maximum) of phytoestrogens in surface waters worldwide.

\subsubsection{Phytoestrogens in Portuguese surface waters}

Concerning the Iberian peninsula west Atlantic coast, it was found that surface waters from the Rivers Douro (ca., 19 g/L BIO-A), Mondego (ca., $5.5 \mu \mathrm{g} / \mathrm{L}$ of FORM and $12 \mu \mathrm{g} / \mathrm{L}$ DAID) 
and Tagus (ca., from $10 \mu / \mathrm{L}$ ) were those holding the higher amounts of phytoestrogens (Table 6). As in these habitats there were occasions when the concentrations of the isoflavones were more than 1,000 times higher than those measured for oestrogens (mainly in spring and summer), it is supposed that those compounds may contribute significantly to endocrine disrupting phenomena occurring in those ecosystems. So, although the phytoestrogens are much less active than oestrogens $\left(E_{2}\right)$ their very high concentrations make them worth studying and relevant in monitoring programs.

\begin{tabular}{|c|c|c|c|c|}
\hline \multirow[t]{2}{*}{$\overline{\text { EDC }}$} & \multirow{2}{*}{$\begin{array}{l}\text { Sampling area } \\
\text { Lima River estuary and Atlantic coast of Viana-Castelo }\end{array}$} & \multicolumn{2}{|c|}{ Concentration (ng/L) } & \multirow{2}{*}{$\begin{array}{l}\text { References } \\
{[64]}\end{array}$} \\
\hline & & 2.9 & -78.5 & \\
\hline \multirow{10}{*}{ DAID } & Ave River estuary and Atlantic coast of Vila-Conde & 7.7 & -74.3 & [61] \\
\hline & Douro River estuary & $<10$ & -888 & [62] \\
\hline & Douro River estuary and Atlantic coast of Porto & 6.7 & -24.2 & {$[63]$} \\
\hline & Mondego River estuary & $<3.0$ & -526 & {$[66]$} \\
\hline & Mondego River and its estuary & 52.9 & - 11,945 & [67] \\
\hline & Tagus River estuary & $\approx 4$ & $-\approx 20$ & Unpublished \\
\hline & Sado River estuary & 8.4 & -160 & [103] \\
\hline & Sado River and its estuary & 3.4 & -32.3 & [59] \\
\hline & Mira River and its estuary & $\approx 5$ & $-\approx 40$ & Unpublished \\
\hline & Ria Formosa & 4.6 & -14.0 & [60] \\
\hline \multirow{11}{*}{ GEN } & Lima River estuary and Atlantic coast of Viana- Castelo & 18.5 & -120.3 & [64] \\
\hline & Ave River estuary and Atlantic coast of Vila-Conde & 36.6 & -682.3 & [61] \\
\hline & Douro River estuary & $<3.2$ & -197 & {$[62]$} \\
\hline & Douro River estuary and Atlantic coast of Porto & 16.6 & - 137.8 & [63] \\
\hline & Mondego River estuary & $<2.6$ & -507 & [66] \\
\hline & Mondego River and its estuary & 127.9 & - 5,093 & {$[67]$} \\
\hline & Tagus River and its estuary & $\approx 5$ & $-\approx 4,500$ & Unpublished \\
\hline & Sado River and its estuary & 8.6 & -100 & [103] \\
\hline & Sado River and its estuary & 24.5 & -113.4 & [59] \\
\hline & Mira River and its estuary & $\approx 3$ & $-\approx 47$ & Unpublished \\
\hline & Ria Formosa & 404.8 & $-1,158$ & {$[60]$} \\
\hline \multirow{8}{*}{ FORM } & Lima River estuary and Atlantic coast of Viana-Castelo & 90.0 & -801.0 & [64] \\
\hline & Ave River estuary and Atlantic coast of Vila-Conde & 83.0 & -362.3 & [61] \\
\hline & Douro River estuary and Atlantic coast of Porto & 68 & -341 & {$[63]$} \\
\hline & Mondego River and its estuary & 25.8 & - 5,495 & [67] \\
\hline & Tagus River and its estuary & $\approx 3$ & $-\approx 8$ & Unpublished \\
\hline & Sado River and its estuary & 423.4 & $-2,605$ & [59] \\
\hline & Mira River and its estuary & $\approx 3$ & $-\approx 91$ & Unpublished \\
\hline & Ria Formosa & 186.3 & $-1,041$ & [60] \\
\hline \multirow{4}{*}{ BIO-A } & Lima River estuary and Atlantic coast of Viana-Castelo & 23.5 & -350.0 & [64] \\
\hline & Ave River estuary and Atlantic coast of Vila-Conde & 99.0 & -398.1 & [61] \\
\hline & Douro River estuary & $<12$ & - 191 & {$[62]$} \\
\hline & Douro River estuary and Atlantic coast of Porto & 728.4 & - 19,091 & [63] \\
\hline
\end{tabular}




\begin{tabular}{llrll}
\hline EDC & Sampling area & Concentration $(\mathbf{n g} / \mathbf{L})$ & References \\
\hline & Mondego River estuary & $<8.4-60$ & {$[66]$} \\
& Mondego River and its estuary & $50.1-590.0$ & {$[67]$} \\
\hline \multirow{2}{*}{ BIO-A } & Tagus River and its estuary & $\approx 6-\approx 85$ & Unpublished \\
& Sado River and its estuary & $10-30$ & {$[103]$} \\
& Sado River and its estuary & $130.8-844.5$ & {$[59]$} \\
& Mira River and its estuary & $\approx 5-$ & $\approx 460$ & Unpublished \\
\hline
\end{tabular}

Table 6. Concentrations (minimum-maximum) of phytoestrogens measured in Portuguese surface waters.

\section{Individual compounds versus total estrogenic load and its endocrine disruption potential}

To better understand and predict the effect of the measured concentrations of all EDCs compiled in this Chapter, in terms of action strength and consequent endocrine disrupting effects, the oestrogenic potency of each compound was estimated relative to that of the standard reference oestrogen, the $\mathrm{EE}_{2}$, the most potent environmental oestrogen at this date. Thus, the average levels of each analysed EDC at every studied area in the west of the Iberian Peninsula were all converted in $E_{2}$ equivalents $\left(E E_{2 e q}\right)$. The use of these units facilitates the interpretation of the data. The $E E_{2 e q}$ estimates of the estrogenic potential of the sixteen EDCs referred in this Chapter followed the next formula [125]:

$$
E E_{2 e q}=C x F
$$

Here, $C$ concerns to the measured concentration of a given EDC and $F$ refers to the $\mathrm{EE}_{2}$ equivalency factor, as determined from in vitro assays [125]. Although this type of interpretation is very useful, the $C$ may vary with the assay and it does not exempt the in vivo testing.

Interpreting the results presented here, in light of that normalization, and joining the EDCs by groups (i.e., oestrogens, APs + BPA, APEOs and phytoestrogens) it can be deduced that before 2005 the Portuguese surface waters taken from the rivers Douro, Mondego and Sado exhibited values of $E E_{2 e q}$ that "hovered" between 24 and $198 \mathrm{ng} / \mathrm{L}$, being the Douro River estuary the habitat with the highest oestrogen load (Table 7). After 2005, possibly due to the application of some of the regulations proposed by WFD, it was observed a significant decrease of the $\mathrm{EE}_{2 \mathrm{eq}}$ in the Douro River estuary surface waters, which displayed values that stand in 12 $\mathrm{ng} / \mathrm{L}$, even considering a larger spectrum of analysed EDCs. For the Mondego and Sado Rivers it is also observed that even analysing almost the twice number of EDCs, the data obtained from surface waters in $2005[66,103]$ had similar $E E_{2 e q}(24 \mathrm{ng} / \mathrm{L})$ than those observed in waters from the same sampling areas in 2010-2011. Besides, from the analysis of Table 7 it is also possible to observe which group of compounds contribute the most to the final values of $E E_{2 e q}$. Thus, it is concluded that by order of importance the compounds that contribute the most for 
the $E E_{2 e q}$ values in the Portuguese surface waters were: (i) oestrogens; (ii) phytoestrogens; (iii) APs + BPA; and (iv) APEOs. So, both oestrogens and phytoestrogens are important "key points" to consider when the purpose of achieving good water quality by 2015 is the main goal of the European Environment Agency (EEA). Overall, it is proposed herein that an improvement of the sewerage system could surely promote reduction of the concentration of oestrogens and eutrophication. In addition, it is also suggested that the authorities should equate ways to reduce impacts caused by the use of products containing APEOs, e.g., by regulating their imports.

\begin{tabular}{|c|c|c|c|c|c|c|}
\hline \multirow{2}{*}{\multicolumn{2}{|c|}{ Sampling areas }} & \multicolumn{4}{|c|}{$\mathrm{EE}_{2 \mathrm{eq}}(\mathrm{ng} / \mathrm{L})$} & \multirow{3}{*}{$\begin{array}{c}\begin{array}{c}\text { Total } \\
\text { (ng/L) }\end{array} \\
32\end{array}$} \\
\hline & & \multirow{2}{*}{$\begin{array}{c}\text { Oestrogens } \\
18\end{array}$} & \multirow{2}{*}{$\frac{\text { APs+BPA }}{0.5}$} & \multirow{2}{*}{$\begin{array}{c}\text { APEOs } \\
0.000\end{array}$} & \multirow{2}{*}{$\begin{array}{c}\text { Phytoestrogens } \\
13\end{array}$} & \\
\hline Lima River & {$[64]$} & & & & & \\
\hline Ave River & {$[61]$} & 9.0 & 0.4 & 0.001 & 12 & 22 \\
\hline Leça River & {$[65]$} & 10 & 0.01 & 0.000 & $N A$ & 10 \\
\hline Douro River & {$[63]$} & 192 & 0.25 & NA & $5.1^{*}$ & 198 \\
\hline Douro River & {$[62]$} & 9.0 & 0.45 & 0.002 & 2.9 & 12 \\
\hline Mondego River & {$[66]$} & 16 & 0.04 & NA & $9.0^{*}$ & 25 \\
\hline Mondego River & [67] & 12 & 2.0 & 0.004 & 58 & 72 \\
\hline Tagus River & Unpublished & $\approx 11$ & $\approx 1$ & $\approx 0$ & $\approx 43$ & 55 \\
\hline Sado River & [103] & 16 & 0.005 & $N A$ & $8.7^{*}$ & 25 \\
\hline Sado River & [59] & 9.2 & 0.6 & 0.001 & 12 & 22 \\
\hline Mira River & Unpublished & $\approx 52$ & $\approx 1$ & $\approx 0$ & $\approx 1$ & 54 \\
\hline Ria Formosa & {$[60]$} & 24 & 0.8 & 0.001 & 28 & 52 \\
\hline
\end{tabular}

Data not available (NA) or ( ${ }^{*}$ ) summations containing different number of analysed EDCs.

Table 7. Estimation of the estrogenic potential of several Portuguese surface waters.

\section{Status of waters in the European Union and in Portugal}

Since the beginning of the implementation of the WFD, the EC was aware that it would not be an easy task to attain the proposed quality goals stated in all EU member states within a limited period of time - 15 years [3]. Therefore, although strict targets ought to be accomplished in all states, it was considered some temporal flexibility to completely achieve the main goals, as it was considered that each nation has its own environmental (and social) characteristics. In this vein, a 2007 report from the EC revealed that nineteen EU states still showed significant weaknesses in the implementation of the WFD and, called attention to the risk of the purposes set for 2015 may not be met. Therefore, in order to coerce the accomplishment of the WFD requirements, the EC appointed the EEA as a periodic gauge which role has been the evaluation of the water quality in each country that assumed to apply the WFD. In this context, during the last evaluation by the EEA, Portugal was identified as having not yet implemented a plan for the management of all national watersheds (Judgment from 21 June 2012 in Case C-223/11, 
Portugal) [126]. As this task was considered essential for the implementation of various articles defined in the WFD, including the Article 8 that aims the implementation of standards for water monitoring, Portugal together with others (Spain, Greece and Luxembourg) were condemned by the Court of Justice of the European Community. Besides this occurrence, in 2013 the WFD published a list of other, most common, defaults recorded in many states [127]: (i) existence of severe gaps in the levels of chemical pollutants from anthropogenic origins in surface waters; (ii) $60 \%$ of groundwater resources in cities were over-exploitation; (iii) $25 \%$ of the groundwater was polluted; (iv) $47 \%$ of the surface waters showed bad ecological status; and $(v) 50 \%$ of the wetlands showed extinction risks of indigenous species. Considering the first item of this list, it is demonstrated the need of implement chemical monitoring programs for all states involved in the implementation of the WFD. As a corollary, we do emphasize herein the relevance of the regular chemical monitoring and the implementation of strategies for reducing the levels of the EDCs referred in this Chapter.

\section{Impact of natural and xenoestrogenic compounds in human health}

Estimating with certainty the contribution of aquatic environmental pollution - namely by the above mentioned EDCs - to the burden of disease in humans is extremely difficult and consequently quite polemic $[10,128]$. This fact comes from the difficulty to measure and link exposures with the health disorders that may occur in humans, as these are not in regular contact with "oestrogenic waters" as aquatic animals. However, the consumption of contaminated drinking water and/or seafood together with some other sporadic contact between humans and contaminated waters, e.g., during recreational activities either in sea or fluvial beaches [60,64], may change some preconception about this issue. In fact, and despite the confounding variables, recent studies have linked the presence of environmental natural oestrogens, phytoestrogens and xenoestrogens with the development of a range of disorders that go from immune deficiencies, birth defects, chronic endocrine diseases to cancer (Table 8).

During the last decade researchers devoted to both environmental health and human oncology have shown an increasing interest in the environmental impacts of EDCs over human health as the chemical structures of some of these chemicals, namely those refereed in this work, resemble that of $\mathrm{E}_{2}$ which is a molecule that evolution maintained conserved amongst different species [10]. This means that, alike fishes and other aquatic animals, the distribution of oestrogen receptors in mammalian/human tissues is so wide that the presence of these EDCs are able to interfere with the orchestration of an important number of pathways, some of which, are close related with the development of cancer [129-132]. Besides, in both fish and mammals high levels of oestrogens induce the production of reactive oxygen species causing hypomethylation and microsatellite instability $[133,134]$; these phenomena, which is an early step in the process of carcinogenesis, cause DNA adducts and other genetic damages, seen, e.g., by the emergence of micronuclei, a fact that was observed by our group in fish caught in areas described here as having high estrogenic loads [135]. 


\begin{tabular}{clc}
\hline \multicolumn{1}{c}{ EDCs } & \multicolumn{1}{c}{ Human health disorders } & References \\
\hline \multirow{2}{*}{$\mathbf{E}_{1}, \mathbf{E}_{2}$ and $\mathbf{E E}_{2}$} & Immune deficiencies & {$[23,24]$} \\
& Ovarian Cancer & {$[136]$} \\
& Cancer in children and adolescent & {$[137]$} \\
& Abnormal prostate development & {$[138]$} \\
\hline & Breast Cancer & {$[10,139]$} \\
& Human reproduction & {$[140]$} \\
BPA and APs & Reproductive development & {$[141]$} \\
& Premature puberty and endometriosis development & {$[142]$} \\
& Fetal development & {$[143]$} \\
& Defects in human male germ cells & {$[144]$} \\
\hline \multirow{2}{*}{ Phytoestrogens } & Breast cancer & {$[145]$} \\
& Hypospadias & {$[146]$} \\
& Puberty disorders & {$[147]$} \\
& Masculine infertility & {$[148]$} \\
& Endocrine modulation & {$[149,150]$} \\
\hline
\end{tabular}

Table 8. Examples of some disorders promoted by the EDCs focused in this Chapter.

Some epidemiologic studies also support the correlation between oestrogenic EDCs and cancer as, it was found that in Europe childhood cancer incidence is having an annual increase of $1 \%$ [137]. This worrying result it is also associated with a rising trend of other cancer types such as the soft tissue sarcoma, brain tumours, germ-cell tumours, lymphomas, renal cancers, leukaemia, breast cancer and lung cancer in women [10,151,152]. These occurrences are much preoccupant and alert all society to the possible risk that these compounds can pose for public health.

\section{Conclusion and perspectives}

As demonstrated in this Chapter, with regard to the xenobiotics that can act as oestrogens there is still much to do in both Portugal and other countries in order to reduce this type of chemical pollution in the surface waters from rivers, estuaries and coastal areas. Thus it would be very useful to conceive national monitoring plans, coordinated in time and space (location of the areas under evaluation), using not only chemical methods but also biological tools (e.g., via the usage of biomarkers). This type of plans, involving and networking public and private agents, would make it possible to assess risks and if measures of prevention and remediation that are being promoted on the ground produce, the desired effects, namely as required by the implementation of the WFD. With regard to research activities done in the west Iberian Peninsula, we seek to continue developing projects that allow the diagnosis of the aquatic systems, not only focusing the attention in the type of EDCs discussed here but also in others judged relevant, such as emerging pharmaceutical compounds, PAHs, PCBs and pesticides some data are already published concerning these compounds [153-159]. Introduction of 
passive sampling methods should be pursued too, to get time-integrated characterizations. In parallel, we also view as utterly important to contribute with knowledge about the mechanisms of action that underlie the disruptive effects in aquatic organisms, as illustrated in works we co-authored [160-169]. At last, it is very relevant to reinforce the efforts to investigate causeeffect associations related with potential long term risks of drinking (inc. tape) waters contaminated with estrogenic compounds, both by monitoring the types and quantities of compounds [170] and by epidemiological approaches [171].

\section{Acknowledgements}

This work was partially supported by the European Regional Development Fund (ERDF), through the COMPETE - Operational Competitiveness Programme, and by national funds, via FCT - Foundation for Science and Technology: projects PTDC/MAR/70436/2006 and PEstC/MAR/LA0015/2013.

\section{Author details}

Maria João Rocha ${ }^{1 *}$ and Eduardo Rocha ${ }^{2}$

*Address all correspondence to: mjsrocha@netcabo.pt

1 Interdisciplinary Centre for Marine and Environmental Research (CIIMAR/CIMAR), University of Porto (UPorto), Portugal. Laboratory of Histology and Embryology, Institute of Biomedical Sciences Abel Salazar (ICBAS), UPorto, Portugal

2 Interdisciplinary Centre for Marine and Environmental Research (CIIMAR/CIMAR), University of Porto (UPorto), Portugal. Laboratory of Histology and Embryology, Institute of Biomedical Sciences Abel Salazar (ICBAS), UPorto, Portugal

\section{References}

[1] Barnett TP, Adam JC, Lettenmaier DP. Potential Impacts of a Warming Climate on Water Availability in Snow-Dominated Regions. Nature 2005; 438(7066) 303-309.

[2] Commission E. The Eu Biodiversity Strategy to 2020. Publications Office of the European Union 2011.

[3] WFD. Directive 2000/60/Ec of the European Parliament and of the Council, in, Official Journal of the European Communities, 2000. 
[4] WFD. Decision No 2455/2001/Ec of the European Parliament and of the Council of 20 November 2001 Establishing the List of Priority Substances in the Field of Water Policy and Amending Directive 2000/60/Ec, in, Official Journal of the European Communities, 2001.

[5] WFD. Directive 2008/105/Ec of the European Parliament and of the Council of 16 December 2008 on Environmental Quality Standards in the Field of Water Policy, Amending and Subsequently Repealing Council Directives 82/176/Eec, 83/513/Eec, 84/156/Eec, 84/491/Eec, 86/280/Eec and Amending Directive 2000/60/Ec of the European Parliament and of the Council in, Official Journal of the European Union, 2008.

[6] WFD. Directive 2013/39/Eu of the European Parliament and of the Council of $12 \mathrm{Au}$ gust 2013 Amending Directives 2000/60/Ec and 2008/105/Ec as Regards Priority Substances in the Field of Water Policy, in, Official Journal of the European Union, 2013.

[7] NIH. Endocrine Disruptors, in, National Institutes of Health U.S. Department of Health and Human Services, 2010.

[8] Kordon C, Gaillard RC. Hormones and the Brain. Research and Perspectives in Endocrine Interactions. In: Springer-Verlag Berlin Heidelberg New York; 2006. p

[9] Tierney KB, Farrell AP, Brauner CJ, (Eds.). Fish Physiology: Organic Chemical Toxicology of Fishes, Academic Press; 2013.

[10] Fucic A, Gamulin M, Ferencic Z, Katic J, Krayer von Krauss M, Bartonova A, Merlo D. Environmental Exposure to Xenoestrogens and Oestrogen Related Cancers: Reproductive System, Breast, Lung, Kidney, Pancreas, and Brain. Environmental Health 2012; 11(Suppl 1) S8.

[11] Ferreira M, Antunes P, Gil O, Vale C, Reis-Henriques MA. Organochlorine Contaminants in Flounder (Platichthys flesus) and Mullet (Mugil cephalus) from Douro Estuary, and Their Use as Sentinel Species for Environmental Monitoring. Aquatic Toxicology 2004; 69(4) 347-357.

[12] Mills LJ, Chichester C. Review of Evidence: Are Endocrine-Disrupting Chemicals in the Aquatic Environment Impacting Fish Populations? Science of the Total Environment 2005; 343(1-3) 1-34.

[13] Ying GG, Kookana RS, Chen ZL. On-Line Solid-Phase Extraction and Fluorescence Detection of Selected Endocrine Disrupting Chemicals in Water by High-Performance Liquid Chromatography. Journal of Environmental Science and Health Part BPesticides Food Contaminants and Agricultural Wastes 2002; 37(3) 225-234.

[14] Lintelmann J, Katayama A, Kurihara N, Shore L, Wenzel A. Endocrine Disruptors in the Environment - (Iupac Technical Report). Pure and Applied Chemistry 2003; 75(5) 631-681. 
[15] Kiparissis Y, Hughes R, Metcalfe C, Ternes T. Identification of the Isoflavonoid Genistein in Bleached Kraft Mill Effluent. Environmental Science and Technology 2001; 35(12) 2423-2427.

[16] Gutendorf B, Westendorf J. Comparison of an Array of in Vitro Assays for the Assessment of the Estrogenic Potential of Natural and Synthetic Estrogens, Phytoestrogens and Xenoestrogens. Toxicology 2001; 166(1-2) 79-89.

[17] Sumpter JP. Endocrine Disrupters in the Aquatic Environment: An Overview. Acta Hydrochimica et Hydrobiologica 2005; 33(1) 9-16.

[18] McLachlan JA, Simpson E, Martin M. Endocrine Disrupters and Female Reproductive Health. Best Practice \& Research Clinical Endocrinology \& Metabolism 2006; 20(1) 63-75.

[19] Milnes MR, Bermudez DS, Bryan TA, Edwards TM, Gunderson MP, Larkin ILV, Moore BC, Guillette LJ. Contaminant-Induced Feminization and Demasculinization of Nonmammalian Vertebrate Males in Aquatic Environments. Environmental Research 2006; 100(1) 3-17.

[20] Scott AP, Sanders M, Stentiford GD, Reese RA, Katsiadaki I. Evidence for Estrogenic Endocrine Disruption in an Offshore Flatfish, the Dab (Limanda limanda L.). Marine Environmental Research 2007; 64(2) 128-148.

[21] Hotchkiss AK, Lambright CS, Ostby JS, Parks-Saldutti L, Vandenbergh JG, Gray LE, Jr. Prenatal Testosterone Exposure Permanently Masculinizes Anogenital Distance, Nipple Development, and Reproductive Tract Morphology in Female Sprague-Dawley Rats. Toxicological Sciences 2007; 96(2) 335-345.

[22] Matthiessen P. An Assessment of Endocrine Disruption in Mollusks and the Potential for Developing Internationally Standardized Mollusk Life Cycle Test Guidelines. Integrated environmental assessment and management 2008; 4(3) 274-284.

[23] Ansar Ahmed S. The Immune System as a Potential Target for Environmental Estrogens (Endocrine Disrupters): A New Emerging Field. Toxicology 2000; 150(1-3) 191-206.

[24] Chalubinski M, Kowalski ML. Endocrine Disrupters - Potential Modulators of the Immune System and Allergic Response. Allergy 2006; 61(11) 1326-1335.

[25] Waring RH, Harris RM. Endocrine Disrupters: A Human Risk? Molecular and Cellular Endocrinology 2005; 244(1-2) 2-9.

[26] Belfroid AC, Van der Horst A, Vethaak AD, Schafer AJ, Rijs GBJ, Wegener J, Cofino WP. Analysis and Occurrence of Estrogenic Hormones and Their Glucuronides in Surface Water and Waste Water in the Netherlands. Science of the Total Environment 1999; 225(1-2) 101-108.

[27] Metcalfe CD, Metcalfe TL, Kiparissis Y, Koenig BG, Khan C, Hughes RJ, Croley TR, March RE, Potter T. Estrogenic Potency of Chemicals Detected in Sewage Treatment 
Plant Effluents as Determined by in Vivo Assays with Japanese Medaka (Oryzias latipes). Environmental Toxicology and Chemistry 2001; 20(2) 297-308.

[28] Peters REM, Courtenay SC, Cagampan S, Hewitt ML, MacLatchy DL. Effects on Reproductive Potential and Endocrine Status in the Mummichog (Fundulus leteroclitus) after Exposure to 17 Alpha-Ethynylestradiol in a Short-Term Reproductive Bioassay. Aquatic Toxicology 2007; 85(2) 154-166.

[29] Furuichi T, Kannan K, Glesy JP, Masunaga S. Contribution of Known Endocrine Disrupting Substances to the Estrogenic Activity in Tama River Water Samples from Japan Using Instrumental Analysis and in Vitro Reporter Gene Assay. Water Research 2004; 38(20) 4491-4501.

[30] Chen CY, Wen TY, Wang GS, Cheng HW, Lin YH, Lien GW. Determining Estrogenic Steroids in Taipei Waters and Removal in Drinking Water Treatment Using HighFlow Solid-Phase Extraction and Liquid Chromatography/Tandem Mass Spectrometry. Science of the Total Environment 2007; 378(3) 352-365.

[31] Peng X, Yu Y, Tang C, Tan J, Huang Q, Wang Z. Occurrence of Steroid Estrogens, Endocrine-Disrupting Phenols, and Acid Pharmaceutical Residues in Urban Riverine Water of the Pearl River Delta, South China. Science of the Total Environment 2008; 397(1-3) 158-166.

[32] Zhao JL, Ying GG, Chen F, Liu YS, Wang L, Yang B, Liu S, Tao R. Estrogenic Activity Profiles and Risks in Surface Waters and Sediments of the Pearl River System in South China Assessed by Chemical Analysis and in Vitro Bioassay. Journal of Environmental Monitoring 2011; 13(4) 813-821.

[33] Brossa L, Marcé RM, Borrull F, Pocurull E. Occurrence of Twenty-Six Endocrine-Disrupting Compounds in Environmental Water Samples from Catalonia, Spain. Environmental Toxicology and Chemistry 2005; 24(2) 261-267.

[34] Pojana G, Gomiero A, Jonkers N, Marcomini A. Natural and Synthetic Endocrine Disrupting Compounds (Edcs) in Water, Sediment and Biota of a Coastal Lagoon. Environment International 2007; 33(7) 929-936.

[35] Jobling S, Beresford N, Nolan M, Rodgers-Gray T, Brighty GC, Sumpter JP, Tyler CR. Altered Sexual Maturation and Gamete Production in Wild Roach (Rutilus rutilus) Living in Rivers That Receive Treated Sewage Effluents. Biology of Reproduction 2002; 66(2) 272-281.

[36] Lange A, Paull GC, Hamilton PB, Iguchi T, Tyler CR. Implications of Persistent Exposure to Treated Wastewater Effluent for Breeding in Wild Roach (Rutilus rutilus) Populations. Environmental Science \& Technology 2011; 45(4) 1673-1679.

[37] Tyler CR, Lange A, Paull GC, Katsu Y, Iguchi T. The Roach (Rutilus rutilus) as a Sentinel for Assessing Endocrine Disruption. Environmental Sciences 2007; 14(5) 235-253. 
[38] van Aerle R, Nolan M, Jobling S, Christiansen LB, Sumpter JP, Tyler CR. Sexual Disruption in a Second Species of Wild Cyprinid Fish (the Gudgeon, Gobio gobio) in United Kingdom Freshwaters. Environmental Toxicology and Chemistry 2001; 20(12) 2841-2847.

[39] Noppe H, Verslycke T, De Wulf E, Verheyden K, Monteyne E, Van Caeter P, Janssen CR, De brabander HF. Occurrence of Estrogens in the Scheldt Estuary: A 2-Year Survey. Ecotoxicology and Environmental Safety 2007; 66(1) 1-8.

[40] Vethaak AD, Lahr J, Schrap SM, Belfroid AC, Rijs GBJ, Gerritsen A, de Boer J, Bulder AS, Grinwis GCM, Kuiper RV, Legler J, Murk TAJ, Peijnenburg W, Verhaar HJM, de Voogt P. An Integrated Assessment of Estrogenic Contamination and Biological Effects in the Aquatic Environment of the Netherlands. Chemosphere 2005; 59(4) 511-524.

[41] Kuch HM, Ballschmiter K. Determination of Endocrine-Disrupting Phenolic Compounds and Estrogens in Surface and Drinking Water by Hrgc-(Nci)-Ms in the Picogram Per Liter Range. Environmental Science \& Technology 2001; 35(15) 3201-3206.

[42] Beck IC, Bruhn R, Gandrass J, Ruck W. Liquid Chromatography-Tandem Mass Spectrometry Analysis of Estrogenic Compounds in Coastal Surface Water of the Baltic Sea. Journal of Chromatography A 2005; 1090(1-2) 98-106.

[43] Cargouet M, Perdiz D, Mouatassim-Souali A, Tamisier-Karolak S, Levi Y. Assessment of River Contamination by Estrogenic Compounds in Paris Area (France). Science of the Total Environment 2004; 324(1-3) 55-66.

[44] Lagana A, Bacaloni A, De Leva I, Faberi A, Fago G, Marino A. Analytical Methodologies for Determining the Occurrence of Endocrine Disrupting Chemicals in Sewage Treatment Plants and Natural Waters. Analytica Chimica Acta 2004; 501(1) 79-88.

[45] Rodriguez-Mozaz S, López de Alda MJ, Barceló D. Monitoring of Estrogens, Pesticides and Bisphenol a in Natural Waters and Drinking Water Treatment Plants by Solid-Phase Extraction-Liquid Chromatography-Mass Spectrometry. Journal of Chromatography A 2004; 1045(1-2) 85-92.

[46] López-Roldán R, de Alda ML, Gros M, Petrovic M, Martín-Alonso J, Barceló D. Advanced Monitoring of Pharmaceuticals and Estrogens in the Llobregat River Basin (Spain) by Liquid Chromatography-Triple Quadrupole-Tandem Mass Spectrometry in Combination with Ultra Performance Liquid Chromatography-Time of FlightMass Spectrometry. Chemosphere 2010; 80(11) 1337-1344.

[47] Arditsoglou A, Voutsa D. Occurrence and Partitioning of Endocrine-Disrupting Compounds in the Marine Environment of Thermaikos Gulf, Northern Aegean Sea, Greece. Marine Pollution Bulletin 2012; 64(11) 2443-2452. 
[48] Aydin E, Talinli I. Analysis, Occurrence and Fate of Commonly Used Pharmaceuticals and Hormones in the Buyukcekmece Watershed, Turkey. Chemosphere 2013; 90(6) 2004-2012.

[49] Zuo Y, Zhang K, Deng Y. Occurrence and Photochemical Degradation of $17 \alpha$-Ethinylestradiol in Acushnet River Estuary. Chemosphere 2006; 63(9) 1583-1590.

[50] Singh S, Azua A, Chaudhary A, Khan S, Willett K, Gardinali P. Occurrence and Distribution of Steroids, Hormones and Selected Pharmaceuticals in South Florida Coastal Environments. Ecotoxicology 2010; 19(2) 338-350.

[51] Sodré FF, Pescara IC, Montagner CC, Jardim WF. Assessing Selected Estrogens and Xenoestrogens in Brazilian Surface Waters by Liquid Chromatography-Tandem Mass Spectrometry. Microchemical Journal 2010; 96(1) 92-98.

[52] Wang L, Ying GG, Zhao JL, Liu S, Yang B, Zhou LJ, Tao R, Su HC. Assessing Estrogenic Activity in Surface Water and Sediment of the Liao River System in Northeast China Using Combined Chemical and Biological Tools. Environmental Pollution 2011; 159(1) 148-156.

[53] Shi J, Liu X, Chen Q, Zhang H. Spatial and Seasonal Distributions of Estrogens and Bisphenol a in the Yangtze River Estuary and the Adjacent East China Sea. Chemosphere 2014; 111(0) 336-343.

[54] Zhang Z, Ren N, Kannan K, Nan J, Liu L, Ma W, Qi H, Li Y. Occurrence of Endocrine-Disrupting Phenols and Estrogens in Water and Sediment of the Songhua River, Northeastern China. Archives of Environmental Contamination and Toxicology 2014; 66(3) 361-369.

[55] Isobe T, Shiraishi H, Yasuda M, Shinoda A, Suzuki H, Morita M. Determination of Estrogens and Their Conjugates in Water Using Solid-Phase Extraction Followed by Liquid Chromatography-Tandem Mass Spectrometry. Journal of Chromatography A 2003; 984(2) 195-202.

[56] Gorga M, Petrovic M, Barceló D. Multi-Residue Analytical Method for the Determination of Endocrine Disruptors and Related Compounds in River and Waste Water Using Dual Column Liquid Chromatography Switching System Coupled to Mass Spectrometry. Journal of Chromatography A 2013; 1295(0) 57-66.

[57] Safe SH. Endocrine Disruptors and Human Health - Is There a Problem? An Update. Environmental Health Perspectives 2000; 108(6) 487-493.

[58] Census. Resultados Definitivos - Portugal, in: I.N.d. Estatística, (Ed.), Lisboa, 2011.

[59] Rocha MJ, Cruzeiro C, Reis M, Rocha E, Pardal MA. Determination of 17 Endocrine Disruptor Compounds and Their Spatial and Seasonal Distribution in the Sado River Estuary (Portugal). Toxicological \& Environmental Chemistry 2013; 95(2) 237-253.

[60] Rocha M, Cruzeiro C, Reis M, Rocha E, Pardal M. Determination of Seventeen Endocrine Disruptor Compounds and Their Spatial and Seasonal Distribution in Ria For- 
mosa Lagoon (Portugal). Environmental Monitoring and Assessment 2013; 185(10) 8215-8226.

[61] Rocha MJ, Cruzeiro C, Rocha E. Quantification of 17 Endocrine Disruptor Compounds and Their Spatial and Seasonal Distribution in the Iberian Ave River and Its Coastline. Toxicological \& Environmental Chemistry 2013; 95(3) 386-399.

[62] Rocha MJ, Cruzeiro C, Rocha E. Development and Validation of a Gc-Ms Method for the Evaluation of 17 Endocrine Disruptor Compounds, Including Phytoestrogens and Sitosterol, in Coastal Waters - Their Spatial and Seasonal Levels in Porto Costal Region (Portugal). Journal of Water \& Health 2013; 11(2) 281-296.

[63] Ribeiro C, Tiritan M, Rocha E, Rocha M. Seasonal and Spatial Distribution of Several Endocrine-Disrupting Compounds in the Douro River Estuary, Portugal. Archives of Environmental Contamination and Toxicology 2009; 56(1) 1-11.

[64] Rocha M, Cruzeiro C, Peixoto C, Rocha E. Annual Fluctuations of Endocrine-Disrupting Compounds at the Lower End of the Lima River, Portugal, and in Adjacent Coastal Waters. Archives of Environmental Contamination and Toxicology 2014; 67(3) 389-401.

[65] Rocha MJ, Ribeiro M, Ribeiro C, Couto C, Cruzeiro C, Rocha E. Endocrine Disruptors in the Leça River and Nearby Porto Coast (Nw Portugal): Presence of Estrogenic Compounds and Hypoxic Conditions. Toxicological \& Environmental Chemistry 2012; 94(2) 262-274.

[66] Ribeiro C, Pardal M, Martinho F, Margalho R, Tiritan M, Rocha E, Rocha M. Distribution of Endocrine Disruptors in the Mondego River Estuary, Portugal. Environmental Monitoring and Assessment 2009; 149(1-4) 183-193.

[67] Rocha M, Cruzeiro C, Reis M, Pardal M, Rocha E. Spatial and Seasonal Distribution of 17 Endocrine Disruptor Compounds in an Urban Estuary (Mondego River, Portugal): Evaluation of the Estrogenic Load of the Area. Environmental Monitoring and Assessment 2014; 186(6) 3337-3350.

[68] Arditsoglou A, Voutsa D. Passive Sampling of Selected Endocrine Disrupting Compounds Using Polar Organic Chemical Integrative Samplers. Environmental Pollution 2008; 156(2) 316-324.

[69] David A, Fenet H, Gomez E. Alkylphenols in Marine Environments: Distribution Monitoring Strategies and Detection Considerations. Marine Pollution Bulletin 2009; 58(7) 953-960.

[70] Knez J. Endocrine-Disrupting Chemicals and Male Reproductive Health. Reproductive BioMedicine Online 2013; 26(5) 440-448.

[71] Rochester JR. Bisphenol a and Human Health: A Review of the Literature. Reproductive Toxicology 2013; 42(0) 132-155. 
[72] Gibson RL. Toxic Baby Bottles. Scientific Finds Leaching Chemicals in Clear Plastic Baby Bottles, in, Environment California Research and Policy Center, 2007, pp. 1-36.

[73] Ying G-G, Williams B, Kookana R. Environmental Fate of Alkylphenols and Alkylphenol Ethoxylates-a Review. Environment International 2002; 28(3) 215-226.

[74] Ahel M, Schaffner C, Giger W. Behaviour of Alkylphenol Polyethoxylates Surfactants in the Aquatic Environment - III. Occurrence and Elimination of Their Persistent Metabolites During Infiltration of River Water to Groundwater. Water Research 1996; 30(1) 37-46.

[75] Warhurst AM. An Environmental Assessment of Alkylphenol Ethoxylates and Alkylphenols, in, 1995.

[76] Wang SL, Chang YC, Chao HR, Li CM, Li LA, Lin LY, Papke O. Body Burdens of Polychlorinated Dibenzo-P-Dioxins, Dibenzofurans, and Biphenyls and Their Relations to Estrogen Metabolism in Pregnant Women. Environmental Health Perspectives 2006; 114(5) 740-745.

[77] Jobling S, Sheahan D, Osborne JA, Matthiessen P, Sumpter JP. Inhibition of Testicular Growth in Rainbow Trout (Oncorhynchus mykiss) Exposed to Estrogenic Alkylphenolic Chemicals. Environmental Toxicology and Chemistry 1996; 15(2) 194-202.

[78] Balch G, Metcalfe C. Developmental Effects in Japanese Medaka (Oryzias latipes) Exposed to Nonylphenol Ethoxylates and Their Degradation Products. Chemosphere 2006; 62 (8) 1214-1223.

[79] Group B. Apeos Investigation Report as of July 2013, in, 2013.

[80] Stachel B, Ehrhorn U, Heemken O-P, Lepom P, Reincke H, Sawal G, Theobald N. Xenoestrogens in the River Elbe and Its Tributaries. Environmental Pollution 2003; 124(3) 497-507.

[81] Céspedes R, Lacorte S, Raldúa D, Ginebreda A, Barceló D, Piña B. Distribution of Endocrine Disruptors in the Llobregat River Basin (Catalonia, NE Spain). Chemosphere $2005 ; 61(11)$ 1710-1719.

[82] EEC. Coucil Directive of 27 July 1976 on the Approximation of the Laws, Regulations and Administrative Provisions of the Member States Relating to Restrictions on the Marketing and Use of Certain Dangerous Substances and Preparations (76/769/Eec), in, 1976.

[83] Azevedo DA, Lacorte S, Viana P, Barceló D. Occurrence of Nonylphenol and Bisphenol-a in Surface Waters from Portugal. Journal of the Brazilian Chemical Society 2001; 12(4) 532-537.

[84] Quirós L, Céspedes R, Lacorte S, Viana P, Raldúa D, Barcelò D, Piña B. Detection and Evaluation of Endocrine-Disruption Activity in Water Samples from Portuguese Rivers. Environmental Toxicology and Chemistry 2005; 24(2) 389-395. 
[85] Staniszewska M, Falkowska L, Grabowski P, Kwasniak J, Mudrak-Cegiolka S, Reindl AR, Sokolowski A, Szumilo E, Zgrundo A. Bisphenol A, 4-Tert-Octylphenol, and 4Nonylphenol in the Gulf of Gdansk (Southern Baltic). Archives of Environmental Contamination and Toxicology 2014; 67(3) 335-347.

[86] Kuch HM, Ballschmiter K. Determination of Endocrine-Disrupting Phenolic Compounds and Estrogens in Surface and Drinking Water by Hrgc-(Nci)-Ms in the Picogram Per Liter Range. Environmental Science \& Technology 2001; 35(15) 3201-3206.

[87] Bolz U, Hagenmaier H, Körner W. Phenolic Xenoestrogens in Surface Water, Sediments, and Sewage Sludge from Baden-Württemberg, South-West Germany. Environmental Pollution 2001; 115(2) 291-301.

[88] Voutsa D, Hartmann P, Schaffner C, Giger W. Benzotriazoles, Alkylphenols and Bisphenol A in Municipal Wastewaters and in the Glatt River, Switzerland. Environmental Science and Pollution Research 2006; 13(5) 333-341.

[89] Liu Y, Zhou JL, Wilding A. Simultaneous Determination of Endocrine Disrupting Phenolic Compounds and Steroids in Water by Solid-Phase Extraction-Gas Chromatography-Mass Spectrometry. Journal of Chromatography A 2004; 1022(1-2) 179-189.

[90] Boyd GR, Palmeri JM, Zhang SY, Grimm DA. Pharmaceuticals and Personal Care Products (Ppcps) and Endocrine Disrupting Chemicals (Edcs) in Stormwater Canals and Bayou St. John in New Orleans, Louisiana, USA. Science of the Total Environment 2004; 333(1-3) 137-148.

[91] Liu Y, Guan Y, Tam N, Mizuno T, Tsuno H, Zhu W. Influence of Rainfall and Basic Water Quality Parameters on the Distribution of Endocrine-Disrupting Chemicals in Coastal Area. Water, Air, \& Soil Pollution 2010; 209(1-4) 333-343.

[92] Wang B, Huang B, Jin W, Zhao S, Li F, Hu P, Pan X. Occurrence, Distribution, and Sources of Six Phenolic Endocrine Disrupting Chemicals in the 22 River Estuaries around Dianchi Lake in China. Environmental Science and Pollution Research 2013; 20(5) 3185-3194.

[93] Duong CN, Ra JS, Cho J, Kim SD, Choi HK, Park J-H, Kim KW, Inam E, Kim SD. Estrogenic Chemicals and Estrogenicity in River Waters of South Korea and Seven Asian Countries. Chemosphere 2010; 78(3) 286-293.

[94] Basheer C, Lee HK, Tan KS. Endocrine Disrupting Alkylphenols and Bisphenol-a in Coastal Waters and Supermarket Seafood from Singapore. Marine Pollution Bulletin 2004; 48(11-12) 1161-1167.

[95] Ciofi L, Ancillotti C, Chiuminatto U, Fibbi D, Checchini L, Orlandini S, Del Bubba M. Liquid Chromatographic-Tandem Mass Spectrometric Method for the Simultaneous Determination of Alkylphenols Polyethoxylates, Alkylphenoxy Carboxylates and Alkylphenols in Wastewater and Surface-Water. Journal of Chromatography A 2014; 1362(0) 75-88. 
[96] Nagy P, Fekete J, Sharma VK. Octylphenol and Nonylphenol in Surface Water of Ráckevei-Soroksári Danube Branch, Hungary. Journal of Environmental Science and Health, Part A 2005; 40(9) 1679-1688.

[97] Loyo-Rosales JE, Schmitz-Afonso I, Rice CP, Torrents A. Analysis of Octyl- and Nonylphenol and Their Ethoxylates in Water and Sediments by Liquid Chromatography/ Tandem Mass Spectrometry. Analytical Chemistry 2003; 75(18) 4811-4817.

[98] Yang X, Liu M, Wang Z, Li Q, Zhang Z. Determination of 4-Tert-Octylphenol in Surface Water Samples of Jinan in China by Solid Phase Extraction Coupled with GCMS. Journal of Environmental Sciences 2013; 25(8) 1712-1717.

[99] Babay PA, Itria RF, Ale EER, Becquart ET, Gautier EA. Ubiquity of Endocrine Disruptors Nonylphenol and Its Mono- and Di-Ethoxylates in Freshwater, Sediments, and Biosolids Associated with High and Low Density Populations of Buenos Aires, Argentina. Clean-Soil Air Water 2014; 42(6) 731-737.

[100] Shao B, Hu J, Yang M, An W, Tao S. Nonylphenol and Nonylphenol Ethoxylates in River Water, Drinking Water, and Fish Tissues in the Area of Chongqing, China. Archives of Environmental Contamination and Toxicology 2005; 48(4) 467-473.

[101] Cladière M, Bonhomme C, Vilmin L, Gasperi J, Flipo N, Tassin B. Modelling the Fate of Nonylphenolic Compounds in the Seine River - Part 1: Determination of in-Situ Attenuation Rate Constants. Science of the Total Environment 2014; 468-469(0) 1050-1058.

[102] Ferguson PL, Iden CR, Brownawell BJ. Distribution and Fate of Neutral Alkylphenol Ethoxylate Metabolites in a Sewage-Impacted Urban Estuary. Environmental Science \& Technology 2001; 35(12) 2428-2435.

[103] Ribeiro C, Pardal M, Tiritan M, Rocha E, Margalho R, Rocha M. Spatial Distribution and Quantification of Endocrine-Disrupting Chemicals in Sado River Estuary, Portugal. Environmental Monitoring and Assessment 2009; 159(1-4) 415-427.

[104] FSA. Food Standards Agency, Working Group on Phytoestrogens and Health of the Committee of Toxicology of Chemicals in Food, Consumer Products and the Environment: Phytoestrogens and Health, in: C. Copyright, (Ed.), COT Report 2003.

[105] Kelly MM, Fleischhacker NT, Rearick DC, Arnold WA, Schoenfuss HL, Novak PJ. Phytoestrogens in the Environment, Ii: Microbiological Degradation of Phytoestrogens and the Response of Fathead Minnows to Degradate Exposure. Environmental Toxicology and Chemistry 2014; 33(3) 560-566.

[106] Ishibashi H, Kobayashi M, Koshiishi T, Moriwaki T, Tachibana K, Tsuchimoto M, Soyano K, Iguchi T, Mori C, Arizono K. Induction of Plasma Vitellogenin Synthesis by the Commercial Fish Diets in Male Goldfish (Carassius auratus) and Dietary Phytoestrogens. Journal of Health Science 2002; 48(5) 427-434.

[107] Latonnelle K, Fostier A, Le Menn F, Bennetau-Pelissero C. Binding Affinities of Hepatic Nuclear Estrogen Receptors for Phytoestrogens in Rainbow Trout (Oncorhynchus 
mykiss) and Siberian Sturgeon (Acipenser baeri). General and Comparative Endocrinology 2002; 129(2) 69-79.

[108] Latonnelle K, Le Menn F, Kaushik SJ, Bennetau-Pelissero C. Effects of Dietary Phytoestrogens in Vivo and in Vitro in Rainbow Trout and Siberian Sturgeon: Interests and Limits of the in Vitro Studies of Interspecies Differences. General and Comparative Endocrinology 2002; 126(1) 39-51.

[109] Hoerger CC, Wettstein FE, Hungerbühler K, Bucheli TD. Occurrence and Origin of Estrogenic Isoflavones in Swiss River Waters. Environmental Science \& Technology 2009; 43(16) 6151-6157.

[110] Mackova Z, Koblovska R, Lapcik O. Distribution of Isoflavonoids in Non-Leguminous Taxa - an Update. Phytochemistry 2006; 67(9) 849-855.

[111] Booth NL, Overk CR, Yao P, Totura S, Deng Y, Hedayat AS, Bolton JL, Pauli GF, Farnsworth NR. Seasonal Variation of Red Clover (Trifolium Pratense L., Fabaceae) Isoflavones and Estrogenic Activity. Journal of Agricultural and Food Chemistry 2006; 54(4) 1277-1282.

[112] Benassayag C, Perrot-Applanat M, Ferre F. Phytoestrogens as Modulators of Steroid Action in Target Cells. Journal of Chromatography B 2002; 777(1-2) 233-248.

[113] Clotfelter ED, Rodriguez AC. Behavioral Changes in Fish Exposed to Phytoestrogens. Environmental Pollution 2006; 144(3) 833-839.

[114] Cheshenko K, Pakdel F, Segner H, Kah O, Eggen RIL. Interference of Endocrine Disrupting Chemicals with Aromatase Cyp19 Expression or Activity, and Consequences for Reproduction of Teleost Fish. General and Comparative Endocrinology 2008; 155(1) 31-62.

[115] Rearick DC, Fleischhacker NT, Kelly MM, Arnold WA, Novak PJ, Schoenfuss HL. Phytoestrogens in the Environment, I: Occurrence and Exposure Effects on Fathead Minnows. Environmental Toxicology and Chemistry. 2014; 3(33) 553-559.

[116] Dolbeth M, Cardoso P, Pardal M. Impact of Eutrophication on the Seagrass Assemblages of the Mondego Estuary (Portugal). In: A.A. Ansari, S. Singh Gill, G.R. Lanza, W. Rast (eds.) Eutrophication: Causes, Consequences and Control. Springer Netherlands; 2011. p225-246.

[117] Hoerger CC, Wettstein FE, Hungerbuehler K, Bucheli TD. Occurrence and Origin of Estrogenic Isoflavones in Swiss River Waters. Environmental Science \& Technology 2009; 43(16) 6151-6157.

[118] Erbs M, Hoerger CC, Hartmann N, Bucheli TD. Quantification of Six Phytoestrogens at the Nanogram Per Liter Level in Aqueous Environmental Samples Using ${ }^{13} \mathrm{C}_{3}$-Labeled Internal Standards. Journal of Agricultural and Food Chemistry 2007; 55(21) 8339-8345. 
[119] Pawlowski S, Ternes T, Bonerz M, Kluczka T, van der Burg B, Nau H, Erdinger L, Braunbeck T. Combined in Situ and in Vitro Assessment of the Estrogenic Activity of Sewage and Surface Water Samples. Toxicological Sciences 2003; 75(1) 57-65.

[120] Kolpin DW, Hoerger CC, Meyer MT, Wettstein FE, Hubbard LE, Bucheli TD. Phytoestrogens and Mycotoxins in Iowa Streams: An Examination of Underinvestigated Compounds in Agricultural Basins. Journal of Environmental Quality 2010; 39(6) 2089-2099.

[121] Kuster M, Azevedo DA, de Alda MJL, Neto FRA, Barcelo D. Analysis of Phytoestrogens, Progestogens and Estrogens in Environmental Waters from Rio de Janeiro (Brazil). Environment International 2009; 35(7) 997-1003.

[122] Kang J, Price WE, Hick LA. Simultaneous Determination of Isoflavones and Lignans at Trace Levels in Natural Waters and Wastewater Samples Using Liquid Chromatography/Electrospray Ionization Ion Trap Mass Spectrometry. Rapid Communications in Mass Spectrometry 2006; 20(16) 2411-2418.

[123] Kawanishi M, Takamura-Enya T, Ermawati R, Shimohara C, Sakamoto M, Matsukawa K, Matsuda T, Murahashi T, Matsui S, Wakabayashi K, Watanabe T, Tashiro Y, Yagi T. Detection of Genistein as an Estrogenic Contaminant of River Water in Osaka. Environmental Science \& Technology 2004; 38(23) 6424-6429.

[124] Wang C, Wang L, Zhao QS, Chen JH, Zheng L, Zheng MG, Zhang RT, Wang ZJ. Cloud Point Extraction Coupled with Hplc-Dad for the Determination of Genistein and Daidzein in River Water. Analytical Methods 2013; 5(15) 3688-3692.

[125] Beck I-C, Bruhn R, Gandrass J. Analysis of Estrogenic Activity in Coastal Surface Waters of the Baltic Sea Using the Yeast Estrogen Screen. Chemosphere 2006; 63(11) 1870-1878.

[126] EUR-Lex. Case C-223/11: Judgment of the Court (Fifth Chamber) of 21 June 2012 European Commission V Portuguese Republic (Failure of a Member State to Fulfil Obligations - Environment - Directive 2000/60/Ec - European Union Water Policy - River Basin District Management Plans - Publication and Notification to the Commission - None - Information and Consultation of the Public on the Envisaged Management Plans - None), in, 2012.

[127] EC. European Comission - a Water Blueprint for Europe, in, Blueprint, 2013.

[128] Briggs D. Environmental Pollution and the Global Burden of Disease. British Medical Bulletin 2003; 68(1-24.

[129] Chen G, Zeng Q, Tse G. Estrogen and Its Receptors in Cancer. Medicinal Research Reviews 2008; 28(6) 954-974.

[130] Gonzales R, Ansar S, Duckles S, Krause D. Androgenic/Estrogenic Balance in the Male Rat Cerebral Circulation: Metabolic Enzymes and Sex Steroid Receptors. J Cereb Blood Flow Metab 2007; 27(11) 1841-1852. 
[131] Lemmen J, Arends R, van Boxtel A, van der Saag P, van der Burg B. Tissue and Time Dependent Estrogen Receptor Activation in Estrogen Reporter Mice. Journal of Molecular Endocrinology 2004; 32(3) 689-701.

[132] Roy D, Liehr J. Estrogen DNA Damage and Mutations. Mutation Research 1999; 424((1-2) 107-115.

[133] Cavalieri E, Stack D, Devanesan P. Molecular Origin of Cancer: Catechol Estrogen-3,4-Quinones as Endogenous Tumor Initiators. Proc Nat Acad Sci USA 1997; 94(20) 10937 - 10942.

[134] Liehr J. Genotoxicity of the Steroidal Oestrogens Oestrone and Oestradiol:Possible Mechanism of Uterine and Mammary Cancer Development. Human Reproduction Update 2001; 7(3) 273-281.

[135] Carrola J, Santos N, Rocha M, Fontainhas-Fernandes A, Pardal M, Monteiro RF, Rocha E. Frequency of Micronuclei and of Other Nuclear Abnormalities in Erythrocytes of the Grey Mullet from the Mondego, Douro and Ave Estuaries-Portugal. Environmental Science and Pollution Research 2014; 21(9) 6057-6068.

[136] Ganmaa D, Sato A. The Possible Role of Female Sex Hormones in Milk from Pregnant Cows in the Development of Breast, Ovarian and Corpus Uteri Cancers. Medical Hypotheses 2005; 65(6) 1028-1037.

[137] Pritchard-Jones K, Kaatsch P, Steliarova-Foucher E, Stiller C, Coebergh J. Cancer in Children and Adolescence in Europe: Developments over 20 Years and Future Challenges. European Journal of Cancer 2006; 42(13) 2183-2190.

[138] Taylor JA, Richter CA, Ruhlen RL, Saal FSV. Estrogenic Environmental Chemicals and Drugs: Mechanisms for Effects on the Developing Male Urogenital System. Journal of Steroid Biochemistry and Molecular Biology 2011; 127(1-2) 83-95.

[139] Kim EJ, Lee D, Chung BC, Pyo H, Lee J. Association between Urinary Levels of Bisphenol-A and Estrogen Metabolism in Korean Adults. Science of the Total Environment 2014; 470 1401-1407.

[140] Sugiura-Ogasawara M, Ozaki Y, Sonta SI, Makino T, Suzumori K. Exposure to Bisphenol A Is Associated with Recurrent Miscarriage. Human Reproduction 2005; 20(8) 2325-2329.

[141] Caserta D, Di Segni N, Mallozzi M, Giovanale V, Mantovani A, Marci R, Moscarini M. Bisphenol A and the Female Reproductive Tract: An Overview of Recent Laboratory Evidence and Epidemiological Studies. Reproductive Biology and Endocrinology 2014; 1237

[142] Dhaini HR, Nassif RM. Exposure Assessment of Endocrine Disruptors in Bottled Drinking Water of Lebanon. Environmental Monitoring and Assessment 2014; 186(9) 5655-5662. 
[143] Lee BE, Park H, Hong YC, Ha M, Kim Y, Chang N, Kim BN, Kim YJ, Yu SD, Ha EH. Prenatal Bisphenol a and Birth Outcomes: Moceh (Mothers and Children's Environmental Health) Study. International Journal of Hygiene and Environmental Health $2014 ; 217(2-3)$ 328-334.

[144] Rouiller-Fabre V, Habert R, Livera G. Effects of Endocrine Disruptors on the Human Fetal Testis. Annales d'Endocrinologie 2014; 75(2) 54-57.

[145] Albini A, Rosano C, Angelini G, Amaro A, Esposito AI, Maramotti S, Noonan DM, Pfeffer U. Exogenous Hormonal Regulation in Breast Cancer Cells by Phytoestrogens and Endocrine Disruptors. Current Medicinal Chemistry 2014; 21(9) 1129-1145.

[146] Carmichael SL, Cogswell ME, Ma C, Gonzalez-Feliciano A, Olney RS, Correa A, Shaw GM, Natl Birth Defects P. Hypospadias and Maternal Intake of Phytoestrogens. American Journal of Epidemiology 2013; 178(3) 434-440.

[147] Patisaul HB. Effects of Environmental Endocrine Disruptors and Phytoestrogens on the Kisspeptin System. In: A.S. Kauffman, J.T. Smith (eds.) Kisspeptin Signaling in Reproductive Biology. New York: Springer; 2013. p455-479.

[148] Eustache F, Mondon F, Canivenc-Lavier MC, Lesaffre C, Fulla Y, Berges R, Cravedi JP, Vaiman D, Auger J. Chronic Dietary Exposure to a Low-Dose Mixture of Genistein and Vinclozolin Modifies the Reproductive Axis, Testis Transcriptome, and Fertility. Environmental Health Perspectives 2009; 117(8) 1272-1279.

[149] Vollmer G, Starcke S, Wober J, Zierau O. Endocrine Modulation and the Fragile Balance of Homeostasis - an Overview. Neuroendocrinology Letters 2002; 23(2) 37-42.

[150] Patisaul HB, Jefferson W. The Pros and Cons of Phytoestrogens. Frontiers in neuroendocrinology 2010; 31(4) 400-419.

[151] Ferlay J, Autier P, Boniol M, Heaune M, Colombet M, Boyle P. Estimates of the Incidence and Mortality in Europe in 2006. Annals of Oncology 2007; 18(3) 581-592.

[152] Giannandrea F, Paoli D, Figà-Talamanca I, Lombardo F, Lenzi A, Gandini L. Effect of Endogenous and Exogenous Hormones on Testicular Cancer: The Epidemiological Evidence. The International Journal Of Developmental Biology 2013; 57(2-4) 255-263.

[153] Madureira TV, Barreiro JC, Rocha MJ, Cass QB, Tiritan ME. Pharmaceutical Trace Analysis in Aqueous Environmental Matrices by Liquid Chromatography-Ion Trap Tandem Mass Spectrometry. Journal of Chromatography A 2009; 1216(42) 7033-7042.

[154] Madureira TV, Rocha MJ, Cass QB, Tiritan ME. Development and Optimization of a Hplc-Dad Method for the Determination of Diverse Pharmaceuticals in Estuarine Surface Waters. Journal of Chromatographic Science 2010; 48(3) 176-182.

[155] Madureira TV, Barreiro JC, Rocha MJ, Rocha E, Cass QB, Tiritan ME. Spatiotemporal Distribution of Pharmaceuticals in the Douro River Estuary (Portugal). Science of the Total Environment 2010; 408(22) 5513-5520. 
[156] Rocha MJ, Ferreira PC, Reis PA, Cruzeiro C, Rocha E. Determination of Polycyclic Aromatic Hydrocarbons in Coastal Sediments from the Porto Region (Portugal) by Microwave-Assisted Extraction, Followed by Spme and Gc-Ms. Journal of Chromatographic Science 2011; 49(9) 695-701.

[157] Rocha MJ, Ribeiro MFT, Cruzeiro C, Figueiredo F, Rocha E. Development and Validation of a Gc-Ms Method for Determination of 39 Common Pesticides in Estuarine Water - Targeting Hazardous Amounts in the Douro River Estuary. International Journal of Environmental Analytical Chemistry 2012; 92(14) 1587-1608.

[158] Madureira TV, Rocha MJ, Cruzeiro C, Rodrigues I, Monteiro RAF, Rocha E. The Toxicity Potential of Pharmaceuticals Found in the Douro River Estuary (Portugal): Evaluation of Impacts on Fish Liver, by Histopathology, Stereology, Vitellogenin and Cyp1a Immunohistochemistry, after Sub-Acute Exposures of the Zebrafish Model. Environmental Toxicology and Pharmacology 2012; 34(1) 34-45.

[159] Madureira TV, Velhote S, Santos C, Cruzeiro C, Rocha E, Rocha MJ. A Step Forward Using Quechers (Quick, Easy, Cheap, Effective, Rugged, and Safe) Based Extraction and Gas Chromatography-Tandem Mass Spectrometry-Levels of Priority Polycyclic Aromatic Hydrocarbons in Wild and Commercial Mussels. Environmental Science and Pollution Research 2014; 21(9) 6089-6098.

[160] Rocha MJ, ReisHenriques MA. Plasma and Urine Levels of $\mathrm{C}_{-{ }_{18},} \mathrm{C}_{-19}$ and $\mathrm{C}_{-21}$ Steroids in an Asynchronous Fish, the Tilapia Oreochromis mossambicus (Teleostei, Cichlidae). Comparative Biochemistry and Physiology C-Pharmacology Toxicology \& Endocrinology 1996; 115(3) 257-264.

[161] Rocha MJ, Reis-Henriques MA. Plasma Levels of $\mathrm{C}_{-18^{-}}, \mathrm{C}_{-{ }_{19}}$ - and C- ${ }_{21}$-Steroids in Captive and Feral Female Sea Bass. Journal of Fish Biology 1999; 55(1) 26-34.

[162] Rocha MJ, Reis-Henriques MA. Steroid Metabolism by Ovarian Follicles of the Sea Bass Dicentrarchus labrax. Comparative Biochemistry and Physiology C-Pharmacology Toxicology \& Endocrinology 2000; 125(1) 85-91.

[163] Rocha MJ, Reis-Henriques MA. Steroid Metabolism by Ovarian Follicles of the Tilapia Oreochromis mossambicus (Teleostei, Cichlidae). Comparative Biochemistry and Physiology B-Biochemistry \& Molecular Biology 1998; 121(1) 85-90.

[164] Castro LFC, Rocha MJ, Lobo-da-Cunha A, Batista-Pinto C, Machado A, Rocha E. The 17 Beta-Hydroxysteroid Dehydrogenase 4: Gender-Specific and Seasonal Gene Expression in the Liver of Brown Trout (Salmo trutta f. fario). Comparative Biochemistry and Physiology B-Biochemistry \& Molecular Biology 2009; 153(2) 157-164.

[165] Ribeiro C, Urbatzka R, Castro LFC, Carrola J, Fontainhas-Fernandes A, Monteiro RAF, Rocha E, Rocha MJ. In Vitro Exposure of Nile Tilapia (Oreochromis niloticus) Testis to Estrogenic Endocrine Disrupting Chemicals: mRNA Expression of Genes Encoding Steroidogenic Enzymes. Toxicology Mechanisms and Methods 2012; 22(1) 47-53. 
[166] Urbatzka R, Rocha E, Reis B, Cruzeiro C, Monteiro RAF, Rocha MJ. Effects of Ethinylestradiol and of an Environmentally Relevant Mixture of Xenoestrogens on Steroidogenic Gene Expression and Specific Transcription Factors in Zebrafish. Environmental Pollution 2012; 164 28-35.

[167] Castro LFC, Lobo-da-Cunha A, Rocha MJ, Urbatzka R, Rocha E. Pex11 Alpha in Brown Trout (Salmo trutta f. fario): Expression Dynamics During the Reproductive Cycle Reveals Sex-Specific Seasonal Patterns. Comparative Biochemistry and Physiology A-Molecular \& Integrative Physiology 2013; 164(1) 207-214.

[168] Silva P, Rocha MJ, Cruzeiro C, Malhao F, Reis B, Urbatzka R, Monteiro RAF, Rocha E. Testing the Effects of Ethinylestradiol and of an Environmentally Relevant Mixture of Xenoestrogens as Found in the Douro River (Portugal) on the Maturation of Fish Gonads - A Stereological Study Using the Zebrafish (Danio rerio) as Model. Aquatic Toxicology 2012; 124 1-10.

[169] Sousa ML, Silva A, Malhao F, Rocha MJ, Rocha E, Urbatzka R. Viability Analysis of Oocyte-Follicle Complexes and Gonadal Fragments of Zebrafish as Baseline for Toxicity Testing. Toxicology Mechanisms and Methods 2014; 24(1) 42-49.

[170] Esteban S, Gorga M, González-Alonso S, Petrovic M, Barceló D, Valcárcel Y. Monitoring endocrine disrupting compounds and estrogenic activity in tap water from Central Spain. Environmental Science and Pollution Research 2014; 21(15) 9297-9310.

[171] Brody JG, Aschengrau A, McKelvey W, Swartz CH, Kennedy T, Rudel RA. Breast cancer risk and drinking water contaminated by wastewater: a case control study. Environmental Health 2006; 5:28. 
